S. Šokčević*

\title{
ZAŠTITA DOSTOJANSTVA I ZDRAVLJA RADNIKA - ZAŠTITA OD MALTRETIRANJA NA RADU I U VEZI S RADOM
}

UDK 331.45:364.271

PRIMLJENO: 24.6 .2015 .

PRIHVAĆENO: 14.12 .2015$.

\begin{abstract}
SAŽETAK: Izvješća državnih institucija i sudska praksa u Hrvatskoj dokazuju da radni uvjeti odstupaju od normativnog sadržaja temeljnog prava radnika Europske unije (EU), a time i radnika u Hrvatskoj, na poštene i pravične radne uvjete u kojima se čuvaju zdravlje, sigurnost i dostojanstvo radnika. To pravo utvrđeno je Poveljom o temeljnim pravima EU-a. Povremeno se u Hrvatskoj predlaže donošenje posebnog zakona o mobbingu koji prijedlog više nije relevantan jer je zaštita radnika od maltretiranja na radu osigurana Zakonom o zaštiti na radu i Pravilnikom o izradi procjene rizika. Normativni sadržaj prava, obveza i odgovornosti subjekata radnog odnosa u vezi s rizikom od maltretiranja na radu i u vezi s radom proizlazi iz pravnih pravila zakona i podzakonskih propisa. Ti propisi doneseni su zbog provedbe pravne stečevine EU-a, pa ih treba tumačiti u skladu s obveznim tumačenjima institucija EU-a, osobito praksom Suda EU-a. Uvažavati treba i obveze Hrvatske iz međunarodnih ugovora Ujedinjenih naroda $i$ Vijeća Europe te praksu njihovih stalnih tijela koja prate primjenu tih ugovora u državama članicama koje obvezuju. Tumačenje mora biti široko, jer dostojanstvo, zdravlje i sigurnost radnika treba štititi ne samo od diskriminatornih ponašanja na radu i u vezi s radom, već od svih loših neželjenih ponašanja koja mogu štetiti navedenim pravima osobnosti.
\end{abstract}

Ključne riječi: dostojanstvo na radu, zdravlje radnika, prava osobnosti, maltretiranje, mobbing, bullying

\section{UVOD}

Normativni sadržaj obveza poslodavca i prava radnika u vezi s maltretiranjem radnika na radu i u vezi s radom nije obrađen u znanstvenoj i stručnoj literaturi u Hrvatskoj nakon stupanja na snagu Zakona o zaštiti na radu ${ }^{1}$ (ZZR) i Pravilnika o izradi procjene rizika ${ }^{2}$. Preostaju radovi iz ranijeg razdoblja koji se odnose na obvezu poslodavca iz Zakona o radu ${ }^{3}(Z R)$ i istovrsna zakona koji mu je prethodio da štiti dostojanstvo rad-

*Dr. sc. Svjetlana Šokčević, profesorica visoke škole u trajnom zvanju, (svjetlana.sokcevic@vss.hr), Visoka škola za sigurnost s pravom javnosti, Ivana Lučića 5, 10000 Zagreb. Stajališta iznesena u ovome radu osobna su stajališta autorice, a ne institucije u kojoj radi. nika od uznemiravanja i spolnog uznemiravanja koje predstavlja zabranjenu diskriminaciju.

Nakon stupanja na snagu Pravilnika o izradi procjene rizika u praksi se postavlja pitanje odnosi li se pojam "maltretiranje“ iz klasifikacije opasnosti, štetnosti i napora na radu i u vezi s radom (Prilog III. Pravilnika), koji obuhvaća "bullying" i "mobbing", na uznemiravanje, zlostavljanje, spolno uznemiravanje i druga neželjena loša ponašanja zabranjena ZR-om, Kaznenim zakonom i drugim zakonima koji se primjenjuju na radne odnose.

Nisu u pitanju tek jezična razmatranja. Nedvojbena spoznaja normativnog sadržaja obveza poslodavca i prava radnika preduvjet je efika- 
snog ostvarivanja tih obveza i zaštite prava. U pitanju je, također, temeljno socijalno pravo radnika Europske unije na radne uvjete koji neće štetiti sigurnosti, zdravlju i dostojanstvu. Pravni poredak EU-a nadređen je pravnom poretku Republike Hrvatske i njegov je sastavni dio od 1. srpnja 2013. Od tog dana radnicima u Hrvatskoj pripadaju sva prava na radu i u vezi s radom utvrđena pravnom stečevinom EU-a, pa i u slučaju da ih Hrvatska nije u potpunosti prenijela u svoj pravni poredak.

\section{PRAVNI OKVIR ZA OSTVARIVANJE I ZAŠTITU DOSTOJANSTVA NA RADU I U VEZI S RADOM}

Uz neželjena loša postupanja na radu i u vezi s radom izravno se veže obveza poslodavca da zaštiti dostojanstvo radnika. Zato se primarno iznose pravna obilježja koncepta dostojanstva na radu i u vezi s radom.

\section{Ujedinjeni narodi}

Preambulom Opće deklaracije o ljudskim pravima $^{4}$ utvrđeno je da je priznanje urođenog dostojanstva te jednakih i neotuđivih prava svih članova ljudske obitelji temelj slobode, pravde i mira u svijetu te da je važno zaštititi ljudska prava vladavinom prava. Svrha je Opće deklaracije postići opće i djelotvorno priznanje i primjenu te poštovanje svih ljudskih prava navedenih $u$ Deklaraciji. Člankom 1. utvrđeno je da se sva ljudska bića rađaju slobodna i jednaka u dostojanstvu i pravima. Člankom 29. utvrđena su moguća ograničenja prava, i to vrlo restriktivno. Naime, ograničenja se smiju odnositi isključivo na osiguranje potrebnog priznanja i poštovanja prava i sloboda drugih te na ispunjenje pravednih zahtjeva morala, javnog reda i općeg blagostanja u demokratskom društvu. Opća deklaracija je neobvezujući međunarodni akt, što nije bila prepreka da u proteklim desetljećima proizvede impresivan učinak na promicanje, poštovanje, priznanje, ostvarivanje, zaštitu i tumačenje ljudskih prava u svjetskim razmjerima.

Urođenost dostojanstva ljudske osobe potvrđuju svojim preambulama Međunarodni pakt o građanskim i političkim pravima te Međunarodni pakt o ekonomskim, socijalnim i kulturnim pravima. ${ }^{5}$ Hrvatska je stranka oba pakta. Odredbe ovih međunarodnih ugovora adresirane su državama koje ih trebaju provesti u svojim pravnim poretcima zakonima i drugim propisima u skladu s legislativnom praksom. Člankom 7. Međunarodnog pakta o ekonomskim, socijalnim i kulturnim pravima zajamčeno je pravo na dostojnu zaradu i dostojan život radnika i njegove obitelji te na zaštitu zdravlja i sigurnost na radu. ${ }^{6}$

Filadelfijska deklaracija koja je prilog Ustava Međunarodne organizacije rada $(M O R)^{7}$ sadrži svrhe i ciljeve te načela koja bi trebala usmjeravati politiku država članica. Opća skupština MOR-a potvrđuje da su sloboda i dostojanstvo kontekst, odnosno preduvjet za ostvarivanje materijalnog i duhovnog napretka. Hrvatska je članica MOR-a, pa je obvezna postupati u skladu s ustavnim odrednicama te organizacije.

Ustav Svjetske zdravstvene organizacije $\mathrm{kroz}^{8}$ holistički pristup definiranju zdravlja neizravno obuhvaća i dostojanstvo radnika. Zdravlje je, naime, duševno, tjelesno i socijalno blagostanje čovjeka. Navedene sastavnice zdravlja neostvarive su u uvjetima u kojima bi se povređivalo dostojanstvo osobe. Ustav je prvi međunarodni dokument koji ostvarenje najviše razine zdravlja za sve utvrđuje kao temeljno ljudsko pravo koje je kasnije potvrđeno i Međunarodnim paktom o ekonomskim, socijalnim i kulturnim pravima. Budući da je Hrvatska članica Svjetske zdravstvene organizacije, njezina postupanja i propisi ne smiju povređivati navedene ustavne odrednice.

\section{Vijeće Europe}

Člankom 26. Europske socijalne povelje (revidirane $)^{9}$ utvrđen je normativni sadržaj prava radnika na dostojanstvo na radu. Države stranke Socijalne povelje obvezuju se promicati svijest, obaviještenost i sprečavanje spolnog uznemiravanja na radu ili u vezi s radom te poduzimati sve odgovarajuće mjere za zaštitu radnika od takvog ponašanja. Obvezuju se, također, promicati svijest, obaviještenost i sprečavanje svakog drugog ponašanja koje nije spolno uznemiravanje, ali je za osudu ili je izrazito negativno i uvredljivo, a usmjereno je na pojedine radnike na radu ili $u$ vezi s radom, kao i poduzimati sve mjere potreb- 
ne za zaštitu radnika od takvog ponašanja. Hrvatska je članica Vijeća Europe, potpisala je revidiranu Socijalnu povelju, ali je nije ratificirala.

\section{Europska unija}

Poveljom o temeljnim pravima Europske unije $^{10}$ (Povelja EU-a), koja je iste pravne snage kao i osnivački ugovori ${ }^{11}$, u članku 31. utvrđeno je pravo radnika EU-a na poštene i pravične radne uvjete. Normativni sadržaj jamči svakom radniku pravo na radne uvjete kojima se čuvaju zdravlje, sigurnost i dostojanstvo, kao i pravo na ograničeno trajanje radnog vremena, dnevni i tjedni odmor te na plaćeni godišnji odmor. Pojam dostojanstvo razumijeva se u vezi s odredbom članka 1. Povelje EU-a na temelju koje je ljudsko dostojanstvo nepovredivo i mora biti poštovano i zaštićeno. U skladu s preambulom ${ }^{12}$, prilikom primjene Povelje EU-a treba uzimati u obzir službena Objašnjenja ${ }^{13}$. U vezi sa člankom 1. Povelje EU-a Objašnjenje upućuje da ljudsko dostojanstvo nije samostalno pravo, već je osnova ljudskih prava te je slijedom prakse Suda $\mathrm{EU}$-a dio pravnog poretka EU-a. ${ }^{14} \mathrm{Ni}$ jedno pravo utvrđeno Poveljom EU-a ne smije se koristiti tako da našteti dostojanstvu druge osobe. Ljudsko dostojanstvo mora se poštovati i onda kada postoji potreba ograničiti neko pravo. $U$ odnosu na normativni sadržaj prava na dostojanstvo na radu iz članka 31. Povelje EU-a Objašnjenja upućuju na primjenu odredaba članka 26. revidirane Socijalne povelje. $U$ pogledu prava na zaštitu zdravlja i sigurnost na radu iz članka 31. Povelje EU-a Objašnjenja upućuju da normativni sadržaj tog prava određuju izvori sekundarnog prava EUa, i to kako okvirna Direktiva 89/391/EEZ tako i pojedinačne direktive ${ }^{15}$. lako je samo potpisala, ali nije ratificirala revidiranu Socijalnu povelju, Hrvatska mora u pogledu normativnog sadržaja temeljnog prava radnika na dostojanstvo na radu iz članka 31. Povelje EU-a primjenjivati članak 26. Socijalne povelje. Jer, ta primjena proizlazi iz obveznog Objašnjenja Povelje EU-a koja obvezuje Hrvatsku istom pravnom snagom kao i osnivački ugovori EU-a. Dakle, radnici u Hrvatskoj ne mogu se pozivati izravno na temelju članka 1. Povelje EU-a na subjektivno pravo na dostojanstvo, jer slijedom Objašnjenja to nije samostalno pravo. Ne mogu se izravno pozivati ni na članak 26. revidirane Socijalne povelje, zato što je Hrvatska nije ratificirala i zato što su te odredbe adresirane državi, a ne izravno poslodavcima i radnicima. Međutim, svaki radnik u Hrvatskoj može se pozivati na temeljno pravo na poštene $\mathrm{i}$ pravične radne uvjete, koje obuhvaća zdravlje, sigurnost i dostojanstvo na radu i u vezi s radom, jer je to samostalno pravo iz članka 31. Povelje EU-a. Pozivanje dolazi u obzir u vertikalnim odnosima uvijek kada se primjenjuju propisi koji su u Hrvatskoj doneseni zbog usklađivanja pravnog poretka s okvirnom i posebnim direktivama EU-a o zaštiti zdravlja, dostojanstva i sigurnosti na radu i u vezi s radom (čl. 51., st. 1. Povelje). To su primarno ZR i ZZR te propisi doneseni zbog provedbe tih zakona. Pozivanje u horizontalnim odnosima moguće je u skladu s praksom Suda EU-a ${ }^{16}$, slijedom koje se utvrđuje odgovornost države te ostvaruje pravo na naknadu štete zbog povrede prava EU-a ${ }^{17}$.

Osim direktivama iz područja zaštite zdravlja i sigurnosti na radu dostojanstvo radnika EU-a, pa i radnika u Hrvatskoj, štiti se i antidiskriminacijskim direktivama ${ }^{18}$ odnosno propisima donesenim u Hrvatskoj zbog provedbe tih direktiva. Tako se dodatno pridonosi zaštiti dostojanstva i zdravlja radnika od eventualnih rizika koji bi proizlazili iz neželjenih loših ponašanja na radu ili $\mathrm{u}$ vezi s radom, odnosno u vezi sa zaposlenjem i obavljanjem zanimanja, no samo pod uvjetom da su u pitanju zabranjeni oblici diskriminacije.

Autonomni Okvirni sporazum o nasilju i uznemiravanju na radu ${ }^{19}$ važan je europski kolektivni ugovor u kojem njegovi potpisnici već u uvodu navode da je uzajamno poštovanje dostojanstva na svim razinama unutar radnog okruženja jedna od temeljnih značajki uspješnih organizacija. Zato su im uznemiravanje i nasilje na poslu potpuno neprihvatljivi, pa ih osuđuju u svim njihovim oblicima. Uznemiravanje i nasilje na radnom mjestu rezultat su neprihvatljivog ponašanja pojedinca ili više osoba koje može imati različite oblike, od kojih je neke lakše prepoznati od drugih. Poslovno okruženje može utjecati na izloženost osoba uznemiravanju i nasilju. Slijedom Sporazuma, u pitanju je uznemiravanje kada se jednoga ili više radnika ili direktora opetovano i namjerno zlostavlja, prijeti im se i/ili ih se ponižava u uvjetima vezanim za posao. Nasilje jest kada se jednoga ili više zaposle- 
nika ili direktora napadne u uvjetima vezanim za posao. Jedan ili više direktora ili radnika mogu provoditi uznemiravanje i nasilje, a namjera ili posljedice mogu biti narušavanje dostojanstva direktora ili radnika, utjecaj na njihovo zdravlje i/ili stvaranje neprijateljskog radnog okruženja. Sporazum u državama članicama provode organizacije koje su članovi potpisnika Sporazuma. ${ }^{20}$

\section{Republika Hrvatska}

Ustav Republike Hrvatske ${ }^{21}$ u članku 3. sadrži najviše vrednote ustavnog poretka koje su temelj za tumačenje Ustava. Među ostalima, navedeni su sloboda, jednakost, poštovanje prava čovjeka i vladavina prava. Odredbom članka 35. jamče se osobne slobode i prava, među kojima je poštovanje i pravna zaštita dostojanstva. $U$ odnosu na gospodarska, socijalna i kulturna prava člankom 55. jamči se pravo na zaradu za slobodan i dostojan život pojedinca i obitelji, a člankom 62. pravo na dostojan život kroz zaštitu materinstva, djece i mladeži. Kada je u pitanju pravo na dostojanstvo, Ustavni sud Republike Hrvatske smatra da je ljudsko dostojanstvo središnja točka od koje se mora polaziti pri uravnoteživanju svih drugih ustavnih vrijednost te da je ljudsko dostojanstvo apsolutno, nederogabilno i nekomparabilno te ga nije moguće ni ograničavati ni vagati. Odstupanje od tog pravila nije dopušteno jer nijedno drugo pojedinačno pravo ili sloboda, odnosno nijedan opći ili javni interes nije dopušteno uspoređivati niti mu je dopušteno dati prednost pred ljudskim dostojanstvom. ${ }^{22}$ Ustavni sud Republike Hrvatske je, također, imao priliku izraziti shvaćanje o vezi između ljudskog dostojanstva i minimuma ekonomskog blagostanja radnika. "Ustavni sud podsjeća da je minimum ekonomskog blagostanja pretpostavka za ostvarenje ljudskog dostojanstva. Djelotvorno ostvarenje ljudskih prava u praksi pretpostavlja osiguranje svakom zaposlenom egzistencijalnog minimuma odnosno "sredstava za čovjeka dostojan život«."23 Preostaje zaključiti da je dostojanstvo u Hrvatskoj ustavno pravo svake osobe, a Ustav joj jamči poštovanje i pravnu zaštitu tog prava.

ZR-om su u članku 7. propisane temeljne obveze i prava iz radnog odnosa. Među ostalim, poslodavac ima pravo pobliže odrediti mjesto i način obavljanja rada, poštujući pri tome prava i dostojanstvo radnika. ${ }^{24}$ Poslodavac je dužan osigurati radniku uvjete za rad na siguran način i na način koji ne ugrožava zdravlje radnika u skladu s posebnim zakonom i drugim propisima. Poslodavac je dužan zaštititi dostojanstvo radnika za vrijeme obavljanja posla od postupanja nadređenih, suradnika i osoba s kojima radnik redovito dolazi u doticaj u obavljanju svojih poslova, ako je takvo postupanje neželjeno i u suprotnosti sa ZR-om i posebnim zakonima. Člankom 26. propisana je obveza poslodavca da donese i objavi pravilnik o radu kojim se uređuju plaće, organizacija rada, postupak i mjere za zaštitu dostojanstva radnika te mjere zaštite od diskriminacije i druga pitanja važna za radnike zaposlene kod toga poslodavca, ako ta pitanja nisu uređena kolektivnim ugovorom. Ako je poslodavac suočen s pritužbom radnika u vezi sa zaštitom dostojanstva od uznemiravanja ili spolnog uznemiravanja, obvezan je provesti postupak u skladu s odredbama članka 134. ZR-a.

Zakon u suzbijanju diskriminacije ${ }^{25}$ osigurava zaštitu i promicanje jednakosti. Zabranjene osnove diskriminacije su rasa, etnička pripadnost, boja kože, spol, jezik, vjera, političko ili drugo uvjerenje, nacionalno ili socijalno podrijetlo, imovno stanje, članstvo u sindikatu, obrazovanje, društveni položaj, bračni ili obiteljski status, dob, zdravstveno stanje, invaliditet, genetsko naslijeđe, rodni identitet, izražavanje ili spolna orijentacija. Člankom 8 . upućuje se na primjenu odredaba tog Zakona, među ostalim, na rad i radne uvjete, socijalno osiguranje i zdravstvenu zaštitu. Zakonom su zabranjeni svi oblici diskriminacije (izravne, neizravne, višestruke, produljene, ponovljene), kao i poticanje na diskriminaciju te se pruža zaštita od viktimizacije. Također, u skladu sa člankom 4. diskriminacijom se smatra propust da se osobama s invaliditetom, prema njihovim specifičnim potrebama, omogući pristup radnom mjestu i odgovarajući uvjeti rada, prilagodbom infrastrukture i prostora, korištenjem opreme i na drugi način koji nije nerazmjeran teret za onoga tko je to dužan omogućiti. Člankom 3. definirani su pojmovi uznemiravanje i spolno uznemiravanje koji su relevantni za primjenu članaka 7. i 134. ZR-a. Uznemiravanje je svako neželjeno ponašanje uzrokovano zabranjenim osnovama diskriminacije koje ima za cilj ili stvarno predstavlja povredu dostojanstva osobe, a uzrokuje strah, neprijateljsko, poniža- 
vajuće ili uvredljivo okruženje. Spolno uznemiravanje je svako verbalno, neverbalno ili fizičko neželjeno ponašanje spolne naravi koje ima za cilj ili stvarno predstavlja povredu dostojanstva osobe, koje uzrokuje strah, neprijateljsko, ponižavajuće ili uvredljivo okruženje. Na uznemiravanje i spolno uznemiravanje primjenjuju se sve ostale odredbe ovog Zakona koje se odnose na diskriminaciju.

Kaznenim zakonom ${ }^{26}$ uvedeno je novo kazneno djelo zlostavljanja na radu koje se progoni po prijedlogu (članak 133.). Riječ je o kaznenom djelu protiv radnih odnosa. Počinitelj je osoba koja na radu ili u vezi s radom drugog vrijeđa, ponižava, zlostavlja ili na drugi način uznemirava i time naruši njegovo zdravlje. Očita je terminološka nespretnost, jer iz formulacije "ili na drugi način uznemirava" proizlazi zaključak da je u biti u pitanju kazneno djelo uznemiravanja na radu, a ne zlostavljanja, a to se uznemiravanje može počiniti zlostavljanjem, vrijeđanjem, ponižavanjem ${ }^{27}$ ili drugim načinom uznemiravanja. Dakle, za zakonodavca je u ovom slučaju uznemiravanje širi pojam od zlostavljanja, pa je naziv kaznenog djela trebao to odraziti. Narušenje zdravlja je u zakonskom biću kaznenog djela, pa djelo nije počinjeno ako nedopuštene radnje nisu prouzročile narušenje zdravlja. Člankom 156. propisano je kazneno djelo spolnog uznemiravanja koje se progoni po prijedlogu. Spolno uznemiravanje je svako verbalno, neverbalno ili fizičko neželjeno ponašanje spolne naravi koje ima za cilj ili stvarno predstavlja povredu dostojanstva osobe, koje uzrokuje strah, neprijateljsko, ponižavajuće ili uvredljivo okruženje. Počinitelj je tko spolno uznemirava drugu osobu kojoj je nadređen ili koja se prema njemu nalazi u odnosu zavisnosti ili koja je posebno ranjiva zbog dobi, bolesti, invaliditeta, ovisnosti, trudnoće, teške tjelesne ili duševne smetnje. Naziv spolno uznemiravanje iz članka 156. dodatno potvrđuje da je i kazneno djelo iz članka 133. trebalo nositi naziv uznemiravanje na radu.

Zakonom o ravnopravnosti spolova ${ }^{28}$ propisano je da se odredbe tog Zakona ne smiju tumačiti ni primjenjivati na način koji bi ograničio ili umanjio sadržaj jamstava o ravnopravnosti spolova koja izviru iz općih pravila međunarodnog prava, pravne stečevine EU-a, Konvencije Ujedi- njenih naroda o uklanjanju svih oblika diskriminacije žena, međunarodnih paktova Ujedinjenih naroda o građanskim i političkim pravima odnosno ekonomskim, socijalnim i kulturnim pravima te Europske konvencije za zaštitu ljudskih prava i temeljnih sloboda. U skladu sa člankom 7 . izravna diskriminacija je svako postupanje uvjetovano spolom kojim se osoba stavlja ili je bila stavljena ili bi mogla biti stavljena u nepovoljniji položaj od druge osobe u usporedivoj situaciji. Neizravna diskriminacija postoji kada neutralna pravna norma, kriteriji ili praksa stavljaju osobe jednoga spola u nepovoljniji položaj u odnosu na osobe suprotnog spola, osim ako je ta pravna norma, kriterij ili praksa objektivno opravdana legitimnim ciljem, a sredstva usmjerena postizanju tog cilja su primjerena i nužna. Na temelju članka 8. uznemiravanje i spolno uznemiravanje predstavljaju diskriminaciju. Uznemiravanje je svako neželjeno ponašanje uvjetovano spolom osobe koje ima za cilj ili koje stvarno predstavlja povredu osobnog dostojanstva i koje stvara neugodno, neprijateljsko, ponižavajuće ili uvredljivo okruženje. Spolno uznemiravanje je svako neželjeno verbalno, neverbalno ili fizičko ponašanje spolne naravi koje ima za cilj ili predstavlja povredu osobnog dostojanstva, a posebice ako stvara neugodno, neprijateljsko, ponižavajuće ili uvredljivo okruženje.

$\mathrm{Na}$ radne odnose primjenjuje se i Zakon o životnom partnerstvu osoba istog spola ${ }^{29}$. Povrede odredaba Zakona mogu prouzročiti povredu dostojanstva radnika koji su sklopili životno partnerstvo. Na temelju članka 4., stavka 2. neformalno životno partnerstvo u području prava i obveza iz radnih odnosa stvara iste učinke koji su posebnim propisima, kojima se uređuju radni odnosi, priznati izvanbračnoj zajednici. Člankom 6., stavkom 3. propisana je zabrana diskriminacije, izravne i neizravne, na temelju sklopljenog životnog patnerstva, seksualne orijentacije i rodnog identiteta. U skladu sa člankom 69. nepovoljno postupanje bilo koje vrste u vezi sa zapošljavanjem, radnim uvjetima i sudjelovanjem na tržištu rada uvjetovano statusom životnog partnerstva predstavlja oblik diskriminacije na temelju seksualne orijentacije i kao takvo je zabranjeno, a prava koja su općim propisom o radu i svim njime propisanim izvorima prava iz radnog odnosa osigurana, bračnim drugovima, 
zajamčena su i životnim partnerima. Člankom 70. propisano je jamstvo zabrane nepovoljnijeg postupanja. Prava i obveze životnih partnera na tržištu rada dopušteno je mijenjati posebnim zakonima kojima se uređuju radni odnosi, poštujući pritom jamstvo zabrane nepovoljnijeg postupanja prema životnim partnerima glede obveza, prava ili povlastica koje se odnose na položaj na tržištu rada od onih koje su pružene bračnim drugovima. Svi propisi o radu tumače se u skladu s navedenim jamstvom.

Zakon o obveznim odnosima ${ }^{30}$ u članku 19. propisuje pravo na zaštitu prava osobnosti, među kojima su pravo na život, tjelesno i duševno zdravlje, ugled, čast, dostojanstvo, ime, privatnost osobnog i obiteljskog života, sloboda i dr. Dakle, Zakonom je propisana otvorena lista prava osobnosti. Odredbom članka 1048. propisano je pravo svake osobe da zahtijeva od suda ili drugog nadležnog tijela da naredi prestanak radnje kojom se povređuje pravo njegove osobnosti i uklanjanje njome izazvanih posljedica. Člankom 1100. propisano je pravo na pravičnu novčanu naknadu u slučaju povrede prava osobnosti. Sud je dosuđuje ako nađe da to težina povrede i okolnosti slučaja opravdavaju. Naknadu dosuđuje neovisno o naknadi imovinske štete, a i kad nje nema. Pri odlučivanju o visini pravične novčane naknade sud će voditi računa o jačini i trajanju povredom izazvanih fizičkih boli, duševnih boli i straha, cilju kojem služi naknada, ali i o tome da se njome ne pogoduje težnjama koje nisu spojive s njezinom naravi i društvenom svrhom. Relevantna pravna shvaćanja izrazio je Ustavni sud Republike Hrvatske:

„U suvremenim demokratskim državama posebno se štiti pravo osobnosti svake ljudske osobe, a ta se neimovinska šteta sastoji od tri oblika neimovinske štete: biološke (zbog povrede tijela), moralne (zbog povrede psihe) i egzistencijalne (zbog povrede svih ostalih prava osobnosti odnosno zbog povrede ljudskog duha).

Hrvatski Zakon o obveznim odnosima ("Narodne novine", broj 35/05.) je u članku 1046. definirao neimovinsku štetu kao povredu prava osobnosti. Drugim riječima, svaka povreda prava osobnosti predstavlja neimovinsku štetu.
Pojam prava osobnosti Zakon o obveznim odnosima daje u članku 19. stavku 2. gdje se kao prava osobnosti u smislu tog Zakona navode: pravo na život, tjelesno i duševno zdravlje, ugled, čast, dostojanstvo, ime, privatnost osobnog i obiteljskog života, sloboda i dr.

Ne predstavlja stoga neimovinsku štetu samo pojava fizičkog ili psihičkog bola ili straha (što je bila koncepcija ZOO iz 1978. godine) ili pak smanjene životne aktivnosti (čega svega, u konkretnom slučaju, po utvrđenju redovnih sudova, nije bilo) nego i svaka povreda osobnosti i dostojanstva prema citiranom članku 19. sada važećeg Zakona o obveznim odnosima." ${ }^{31}$

Iz navedenog pregleda pravnih izvora i sudske prakse očito je mnoštvo definicija koje su bliske, ali i dovoljno različite da uzrokuju potrebu pažljivo sagledati i tumačiti normativni sadržaj subjektivnog prava radnika u Hrvatskoj na zaštitu dostojanstva na radu kada je ugroženo postupcima koji se mogu podvesti pod pojmove uznemiravanje, spolno uznemiravanje, maltretiranje, zlostavljanje, mobbing, bullying i njima slične, a kojima se označavaju neželjena i neprihvatljiva loša ponašanja na radu i u vezi s radom. Očita je pojmovna nedosljednost zakonodavca kojoj je vjerojatno pridonijelo usklađivanje zakona s pravnom stečevinom EU-a, ali je ne može opravdati.

Iz ukupnosti relevantnog pravnog okvira proizlazi da se radnik u Hrvatskoj ne može odreći dostojanstva na radu, ono se ne može ograničiti ni dijeliti, urođeno je ljudskoj osobi i sastavnica je svih prava na radu i u vezi s radom. Poslodavac mora štititi pravo radnika na dostojanstvo na radu te mu osigurati radne uvjete koji neće štetiti tjelesnom i duševnom zdravlju te dostojanstvu radnika kao zaštićenim pravima osobnosti. Uznemiravanje i spolno uznemiravanje primjer su loših ponašanja na radu i u vezi s radom koja mogu štetiti pravima osobnosti radnika. Ta su ponašanja kaznena djela. Istovremeno su oblici diskriminacije, ako su neželjena i povezana s nekom od zabranjenih osnova diskriminacije. Međutim, poslodavac mora pružiti radniku zaštitu od svih neželjenih loših ponašanja, pa i onih koja nisu diskriminatorna, uvijek kada nalazi da mogu biti prijetnja zdravlju, dostojanstvu i sigurnosti radnika na radu i u vezi s radom, jer je 
osnovna obveza poslodavca procijeniti sve rizike na radu te zaštititi radnike od svih rizika. ${ }^{32} \mathrm{U}$ odnosu na obveze poslodavca, primarne su važnosti obveze Hrvatske, jer su joj izravno adresirane odredbe međunarodnih ugovora i pravne stečevine EU-a kojima se štiti pravo na zdravlje, sigurnost i dostojanstvo na radu i u vezi s radom. Slijedom tih obveza Hrvatska mora pravnim poretkom, osobito vladavinom prava, osigurati sve potrebne preduvjete za efikasno poštovanje (to respect), zaštitu (to protect) i ostvarivanje dostojanstva (to fulfil), pri čemu ostvarivanje mora omogućiti (to facilitate), osigurati (to provide) i unapređivati (to promote).

\section{MALTRETIRANJE KAO RIZIK RADA U HRVATSKOJ}

\section{Terminološke napomene}

Učinci povrede dostojanstva na radu i $u$ vezi s radom na zdravlje radnika istraživačima su zanimljiva tema u svim dijelovima svijeta. ${ }^{33}$ Prednjači dinamika empirijskih i teorijskih istraživanja koja se provode za potrebe institucija EU-a. ${ }^{34}$ Nesporna je korist istraživačkih rezultata jer pridonose uočljivosti štetnih posljedica za tjelesne, duševne i socijalne sastavnice zdravlja radnika, odnosno za blagostanje radnika koji su izloženi lošim neželjenim ponašanjima na radu i u vezi s radom. Međutim, svakim novim istraživanjem pridonosi se održavanju terminoloških razlika ${ }^{35}$ koje se mogu razumjeti kao dokaz istraživačke kreativnosti, ali istovremeno umanjuju vjerojatnost jednoobrazne primjene istraživačkih rezultata. To se osobito uočava u državama članicama EU-a kojima je zajednička pravna stečevina iz područja zaštite zdravlja, dostojanstva i sigurnosti radnika na radu. ${ }^{36} \mathrm{U}$ pravnom pogledu, pak, za efikasno ostvarivanje i zaštitu prava potrebna je mjera terminološke stabilnosti odnosno izvjesnosti, no teško ju je prepoznati u državama članicama, a slično je i u institucijama EU-a. Primjerice, Europski parlament je 2011. prihvatio Rezoluciju ${ }^{37}$ kojom izražava žaljenje da u europskim razmjerima još ne postoji jedinstvena definicija pojma moral harassment. ${ }^{38}$ Drugi primjer su Smjernice Europske komisije ${ }^{39}$ kojima želi poslodavcima, radnicima i njihovim predstavnicima te stručnjacima zaštite na radu pomoći da pravilno i u potpunosti primijene Direktivu 89/391/EEZ u području psihosocijalnih rizika te zaštite mentalnog zdravlja na radu i u vezi s radom. U pojmovniku tog izdanja definiran je pojam "harassment (bullying, mobbing) at work". Odnosi se na uznemiravanje, vrijeđanje, napade, socijalno isključivanje osobe ili negativno djelovanje na radne zadatke koja negativna aktivnost se ponavlja, redovita je i traje određeno vrijeme. Treći je primjer stručni izvor primarno namijenjen poslodavcima te radnicima i njihovim predstavnicima, a tema je bullying. ${ }^{40}$ Terminološke nedosljednosti postoje i u prijevodima pojma harassment iz Okvirnog sporazuma socijalnih partnera o uznemiravanju i nasilju na radu. ${ }^{41}$ Očita je zamagljenost sadržaja i razlika između pojmova harassment, moral harassment, mobbing $i$ bullying koja proizlazi iz različitih definicija i nedosljednog korištenja tih pojmova. Tako su se ustalila sva četiri, iako bi ih mogao zamijeniti tek jedan pažljivo definiran pojam koji bi se primjenjivao sustavno i dosljedno.

Ponekad, međutim, ni dosljedna dugotrajna uporaba ne pomaže. Prilika je, naime, upozoriti da je u prijevodu na hrvatski jezik revidirane Europske socijalne povelje pojam „spolno uznemiravanje", koji se niz godina dosljedno i jednoznačno koristi u propisima i stručnoj literaturi u Hrvatskoj, zamijenjen pojmom „spolno napastovanje".

U klasifikaciji opasnosti, štetnosti i napora na radu koja je priložena Pravilniku o izradi procjene rizika u skupini psihofizioloških napora naveden je pojam "maltretiranje" koji obuhvaća bullying i mobing. Međutim, pojam "maltretiranje" ne primjenjuje se u Hrvatskoj u ostalim pravno relevantnim propisima o radnim odnosima i radnim uvjetima, čije su najvažnije odredbe, pa i terminološke posebnosti, već elaborirane u prethodnom poglavlju. Za pravilnu primjenu Pravilnika o izradi procjene rizika važno je odrediti normativni sadržaj obveze poslodavca da zaštiti radnike od "maltretiranja" i njegovih sastavnica bullyinga i mobinga, kao i normativni sadržaj subjektivnog prava radnika da traži tu zaštitu ako mu nije pružena, ili ako pruženu zaštitu smatra neučinkovitom. S ciljem pridonošenja jasnoći izlaganja u nastavku se primjenjuju pojmovi iz Pravilnika, iako u jezičnom pogledu oni nisu najbolji izbor. ${ }^{42}$ Pojam maltretiranje je 
prihvatljiv kao nadređeni pojam koji označava cjelinu u čijem su obuhvatu sva loša postupanja i različiti propisani pojmovi koji ih partitativno označuju (mobbing, bullying, uznemiravanje, spolno uznemiravanje, zlostavljanje, vrijeđanje, ponižavanje, zastrašivanje, napastovanje, uzrokovanje neprijateljskog okruženja i sl.). Međutim, to je riječ stranog podrijetla ${ }^{43}$. U Pravilniku je korištena i posuđenica burnout, iako bi bolja zamjena bio pojam „psihičko sagorijevanje" ${ }^{444}$.

Upravo navedeno terminološko obilje u praksi moglo bi zasjeniti potrebu da se precizno utvrdi normativni sadržaj obveza poslodavca i prava radnika u vezi s maltretiranjem na radu. ZZR i Pravilnik o izradi procjene rizika su propisi doneseni zbog provedbe prava EU-a, pa ih treba sagledavati u smislu Povelje EU-a koja štiti zdravlje, sigurnost i dostojanstvo na radu kao važno socijalno pravo radnika u svim državama članicama, te u smislu odgovarajuće prakse Suda EU$\mathrm{a}^{45}$. Tumačenje obveza i prava mora biti široko i treba uzeti u obzir obvezna Obrazloženja Povelje EU-a. Također, treba uvažavati praksu Suda EU-a iz koje proizlazi pravno shvaćanje da se temeljna socijalna prava radnika moraju tumačiti široko, a iznimke odnosno ograničenja vrlo restriktivno. ${ }^{46}$ Naime, ta su prava namijenjena radnicima koji su nesporno ekonomski slabija strana radnog odnosa i ugovora o radu. ${ }^{47}$ Zato se tumačenjem mora postići to da je pravo dostupno najširem krugu adresata te da uskrata prava, bila djelomična ili cjelovita, treba obuhvatiti što je moguće manji broj adresata. ${ }^{48}$ Kada su u pitanju pojmovi "radno okruženje", "zdravlje" i "sigurnost" iz Ugovora o funkcioniranju Europske unije, Sud EU-a utvrdio je da ih treba tumačiti široko u skladu s preambulom Ustava Svjetske zdravstvene organizacije, jer su sve države članice EU-a istovremeno i članice Svjetske zdravstvene organizacije. ${ }^{49}$

\section{Prava i obveze u vezi s maltretiranjem na radu i u vezi s radom}

Slijedom napomena u prethodnom odjeljku, maltretiranje kao rizik na radu i u vezi s radom u Hrvatskoj treba razumjeti u širokom smislu. Njime treba obuhvatiti sva neželjena loša ponašanja koja se mogu dogoditi odnosno poduzeti na radu ili u vezi s radom i koja mogu naštetiti zdravlju, dostojanstvu i sigurnosti jednog ili više radnika. Istim mjerama poslodavac mora obuhvatiti odnosno zaštititi i osobe na radu (čl. 3., st. 1., t. 10. u vezi sa čl. 4., st. 4. ZZR-a). Procjena rizika od maltretiranja na radu i u vezi s radom mora se odnositi na sva vertikalna i horizontalna neželjena loša ponašanja, odnosno obuhvatiti potencijalna ponašanja radniku nadređenih oso$\mathrm{ba}^{50}$, suradnika i osoba s kojima radnik redovito dolazi u doticaj u obavljanju svojih poslova (čl. 7., st. 5. ZR-a). Saznanja o tome poslodavac će crpiti iz prošlih loših neželjenih događaja, ako ih je bilo, a ako još nije bio u prilici rješavati pritužbe radnika zbog maltretiranja treba osigurati da sva relevantna zapažanja radnika budu prikupljena i uvažavana tijekom postupka procjene rizika (čl. 7., st. 3. Pravilnika o izradi procjene rizika). Prvo, to je važno poslodavcima, jer imaju zakonsku obvezu i odgovornost štititi radnike od svih rizika na radu i u vezi s radom, a zaštitu temeljiti na procjeni svih rizika koja mora odgovarati u svakom trenutku stvarnom stanju odnosno radnim uvjetima (čl. 18. ZZR-a). $U$ pitanju je odgovornost koje se poslodavac ne može osloboditi, neovisno kako je organizirao obavljanje poslova zaštite na radu (čl. 19. ZZRa). Zato poslodavcima nije $u$ interesu da ih preusko tumačenje odnosno razumijevanje pojma maltretiranje navede na normativni sadržaj koji neće obuhvatiti sve neželjene loše postupke koji mogu naštetiti zdravlju, dostojanstvu i sigurnosti radnika. Drugo, obveza preventivnog djelovanja ima prednost pred reaktivnim i reparatornim aktivnostima poslodavca, kakve su npr. zakonske obveze koje poslodavac ima u vezi sa zaštitom dostojanstva radnika od onih oblika uznemiravanja i spolnog uznemiravanja koji predstavljaju diskriminaciju. Tu se pruža tek zakašnjela zaštita, nakon što je radnik već bio izložen uznemiravanju, dobio je zakonski status žrtve i pokreće postupak kojim se želi zaštititi. Opća načela prevencije (čl. 11. ZZR-a) idu u suprotnom smjeru, tj. u smjeru generalnog proaktivnog preventivnog djelovanja (izbjegavanje rizika, procjenjivanje rizika, sprečavanje rizika na izvoru, prednost primjene skupnih mjera zaštite nad pojedinačnim, ublažavanje napora s ciljem smanjenja njihovog štetnog učinka na zdravlje itd.). Na ove zaključke upućuju i Smjernice Europske komisije za primjenu okvirne Direktive 89/391/EEZ za zaštitu duševnog zdravlja na radu. Svaka odredba okvirne Direktive, a to znači i svaka odredba 
ZZR-a, treba se primijeniti na psihosocijalne rizike u jednakoj mjeri kao i na ostale vrste rizika. Također, Smjernice detaljno upućuju na vezu između obveza poslodavca propisanih brojnim pojedinačnim direktivama, psihosocijalnih rizika na radu i u vezi s radom te duševnog zdravlja radnika. Te veze su relevantne i za sve pravilnike koji se primjenjuju uz ZZR, jer su njima pojedinačne direktive prenesene $u$ domaći pravni poredak. Treće, slijedom ZZR-a i ZR-a radnik ima pravo potraživati od poslodavca efikasnu zaštitu temeljnog prava na radne uvjete kojima se čuvaju njegovo zdravlje, sigurnost i dostojanstvo, tj. temeljnog prava na poštene i pravične radne uvjete. Četvrto, radnik ima zakonsko pravo u građanskom sudskom postupku štititi svoja prava osobnosti na dostojanstvo te na tjelesno i duševno zdravlje i ima pravo na naknadu štete. Pri tome je važna težina povrede i okolnosti slučaja, na koje činjenice poslodavac može djelovati proaktivnim preventivnim mjerama. Na kraju, radnik ima pravo pokrenuti kazneni postupak u kojem je narušenje zdravlja važan element bića kaznenog djela zlostavljanja na radu. Međutim, i tu posljedicu poslodavac može spriječiti proaktivnim preventivnim djelovanjima.

Dakle, poslodavac se ne treba pouzdati isključivo u primjenu odredaba ZR-a i Zakona u suzbijanju diskriminacije te vjerovati da je provedbom odredaba o pritužbi radnika zbog uznemiravanja na radu ili spolnog uznemiravanja osigurao zaštitu radnika od maltretiranja kao rizika na radu i u vezi s radom iz Pravilnika o izradi procjene rizika. ${ }^{51}$

\section{ZAŠTITA RADNIKA OD MALTRETIRA- NJA NA RADU I U VEZI S RADOM}

\section{Preventivna djelovanja}

\section{Obveze Hrvatske}

Obveze Hrvatske kao članice EU-a proizlaze iz odredaba članka 31. Povelje EU-a, u vezi sa člankom 26. revidirane Europske socijalne povelje, kao i iz sekundarnog prava EU-a za zaštitu zdravlja, dostojanstva i sigurnost radnika na radu i u vezi s radom. Hrvatska mora osigurati legislativnim i drugim mjerama promicanje svi- jesti, obaviještenost i sprečavanje svih loših neželjenih ponašanja koja su za osudu ili izrazito negativna i uvredljiva, a usmjerena su na pojedine radnike, uključujući spolno uznemiravanje, te mora poduzeti sve potrebne mjere za zaštitu zdravlja, dostojanstva i sigurnosti radnika od tih ponašanja. S tim ciljem mora prenijeti u potpunosti i na vrijeme u domaći pravni poredak sve pravne zahtjeve iz pravne stečevine EU-a kojima se štiti zdravlje, dostojanstvo i sigurnost radnika na radu i u vezi s radom i mora osigurati široko tumačenje tih prava teleološkom metodom, uvažavajući opća načela prava, opća načela prevencije, praksu Suda EU-a, kao i praksu koja je rezultat sustavnog nadzora nad primjenom relevantnih međunarodnih ugovora Ujedinjenih naroda, osobito Međunarodne organizacije rada, te Vijeća Europe. To su minimalne obveze koje Hrvatska ima u vezi s temeljnim pravom radnika EU-a na poštene i pravične radne uvjete.

Neuspjehe država članica Sud EU-a kažnjava primjenom načela izravnog učinka prava EU-a, a kada to nije moguće, pravnim shvaćanjem o pravu oštećene osobe na naknadu štete od države koja nije ostvarila obveze iz osnivačkih ugovora, osobito obvezu lojalne provedbe prava EU-a. S tim u vezi uočljiv je propust zakonodavca iz članka 101., stavka 5. ZZR-a. Pravna stečevina EU-a o zaštiti na radu postala je 1. srpnja 2013. sastavni dio domaćeg pravnog poretka. Od toga dana mora se primjenjivati obveza poslodavca iz sekundarnog prava EU-a da procijeni sve rizike na radu, zaštiti radnike od svih rizika te da procjena u svakom trenutku odgovara stvarnom stanju na mjestima rada. Odgoda usklađivanja procjene s odredbama ZZR-a znači da postoji zakonsko pravo poslodavaca da još neko dulje vrijeme ne moraju procijeniti rizik od maltretiranja na radu i u vezi s radom, jer iz propisa koji su bili na snazi prije ZZR-a nije proizlazila ta obveza na način na koji sada nedvosmisleno proizlazi iz Pravilnika o izradi procjene rizika i priložene klasifikacije opasnosti, štetnosti i napora. Međutim, obveza proizlazi iz pravne stečevine EU-a od 1. srpnja 2013. Dodatni je propust ministra što je Pravilnikom utvrdio primjere poslova s malim rizicima, među kojima su poslovi pri obavljanju kojih su radnici izloženi psihosocijalnim rizicima odnosno maltretiranju na radu, što uopće nije uzeo u obzir. Zato je i to normativno 
rješenje u suprotnosti s pravnom stečevinom EUa, iako je označeno samo kao „primjer". Naime, navedeno je u obvezujućem pravnom aktu, a ne u npr. neobvezujućim smjernicama.

\section{Obveze poslodavaca}

$\mathrm{Na}$ preventivnoj razini djelovanja obveze poslodavca proizlaze iz ZZR-a i Pravilnika o izradi procjene rizika. Obuhvaćaju sva loša neželjena ponašanja koja mogu naštetiti zdravlju, dostojanstvu i sigurnosti radnika, a ne samo ona koja prema posebnim propisima predstavljaju diskriminaciju. Zdravlje treba razumjeti u smislu definicije Svjetske zdravstvene organizacije odnosno Konvencije Međunarodne organizacije rada $155^{52}$. Važno je obuhvatiti i duševni aspekt zdravlja, također prema definiciji Svjetske zdravstvene organizacije, prema kojoj je duševno zdravlje stanje dobrobiti u kojem pojedinac ostvaruje svoje potencijale, može se nositi s normalnim životnim stresom, može raditi produktivno i plodno te je sposoban pridonositi zajednici.

Prevencija na primarnoj razini kombinacija je objektivnog i subjektivnog pristupa poslodavca te obuhvaća procjenu rizika (objektivno sagledavanje ukupnog konteksta radnih uvjeta, radnog okruženja, odnosa na radu i u vezi s radom, svih mogućih loših neželjenih ponašanja, uz uvažavanje subjektivnih odnosno osobnih iskustava i stajališta radnika). Primarna prevencija obuhvaća, također, primjenu preventivnih mjera u skladu s procjenom rizika, pravilima zaštite na radu i općim načelima prevencije, posebno u odnosu na posebno osjetljive skupine radnika. Važno je obuhvatiti prevenciju stresa na radu (čl. 51. ZZRa), jer ako poslodavac ne osigura u svakom pogledu zaštitu radnika od stresa na radu i u vezi s radom (npr. od loše komunikacije i međuljudskih odnosa), posljedica može biti prerastanje stresa u maltretiranje. Iz definicije duševnog zdravlja, kako ju je oblikovala Svjetska zdravstvena organizacija, proizlazi jasna poruka da svaki stres nije neprihvatljiv („može se nositi s normalnim životnim stresom"), što treba uzimati u obzir prilikom procjene rizika na radu i u vezi s radom. Poslodavac treba paziti da njegovu pasivnost odnosno propust da se proaktivno odnosi prema zaštiti radnika od neželjenih ponašanja - ne bi neki radnici, koji se upravo tako ponašaju, razu- mjeli kao prešutno odobrenje da nastave s neželjenim ponašanjem. Saznanja o mogućoj izloženosti maltretiranju na radu i u vezi s radom i mjerama koje poduzima poslodavac da otkloni navedeni rizik radnik treba dobiti već u trenutku zasnivanja radnog odnosa (čl. 8., st. 2. i 3. i čl. 26., st. 1. ZR-a te čl. 18., st. 2. i čl. 32., st. 1. -5. ZZR-a), kao i tijekom osposobljavanja za rad na siguran način (čl. 27. ZZR-a). Također, u pravilniku o radu (čl. 19., st. 2. ZZR-a u vezi sa čl. 26., st. 1. ZR-a) poslodavac treba urediti sva važna pitanja u vezi sa zabranom ponašanja koja predstavljaju oblike maltretiranja radnika na radu $\mathrm{i}$ u vezi s radom (ovlasti i odgovornosti ovlaštenika, prava i obveze radnika, preventivni doprinos stručnjaka zaštite na radu i dr.).

Na sekundarnoj razini prevencija obuhvaća individualiziran pristup poslodavca. Primjerice, poslodavac organizira dodatno osposobljavanje onih radnika za koje je utvrdio da ne primjenjuju u dovoljnoj mjeri pravila primarne prevencije, dodatno osposobljava rukovodne radnike iz područja komunikacijskih vještina, ili pak radniku čije je ponašanje neprihvatljivo daje pisano upozorenje na radne obveze i ukazuje na mogućnost otkaza u slučaju nastavka povrede tih obveza, ili mu izvanredno otkazuje ugovor o radu ${ }^{53}$ i sl. Ako izostaju doprinosi poslodav$\mathrm{ca}$, na sekundarnoj razini prevencije moguća je aktivnost radnika i njihovih predstavnika kako bi na drugi način ostvarili prava koja im pripadaju. Primjerice, nakon što su se neuspješno pokušali savjetovati s poslodavcem, oni se mogu obratiti nadležnom inspektoru te tražiti da provede nadzor i upravnom mjerom navede poslodavca da dopuni procjenu rizika pri izradi koje nije obuhvatio rizik od maltretiranja na radu i u vezi s radom (čl. 92., st. 1., t. 1. ZZR-a) te da tu dopunjenu procjenu učini dostupnom na mjestima rada (čl. 18., st. 2. ZZR-a). To je osobito važno kod poslodavca kod kojeg su radnici već bili izloženi tom riziku. Kako jednokratna procjena rizika nije dostatna, u sklopu sekundarnih preventivnih djelovanja bilo bi korisno da poslodavac provodi povremena istraživanja organizacijske kulture sigurnosti i organizacijske klime u vezi s maltretiranjem na radu i u vezi s radom. Aktivnost je korisna jer otkriva mogući cinizam koji se često javlja kao reakcija radnika na propuste poslodavca da provede ono što deklarira u javnosti 
da je proveo (npr. odjel marketinga promiče u javnosti percepciju o uspješnom poslodavcu $s$ korektnim radnim uvjetima, a radnici su istovremeno svjesni da rade u ponižavajućim uvjetima u kojima su prijetnje negativnim iskustvima, npr. otkazom, smanjenjem plaće, zabranom korištenja godišnjeg odmora i sl., uobičajeni sadržaji komunikacije nadređenih osoba s radnicima sa čim u vezi poslodavac ništa ne poduzima). Rezultati istraživanja mogu upozoriti na potrebu primjene dodatnih preventivnih mjera.

\section{Reaktivna i reparatorna djelovanja}

Tercijarna djelovanja poslodavca nemaju preventivan učinak u smislu općih načela prevencije iz ZZR-a i sekundarnog prava EU-a. Ona jedino mogu smanjiti štetu koja je već nastala te pomoći radniku koji je žrtva maltretiranja na radu i u vezi s radom da se ponovno uključi u radno okruženje i uspješno obavlja svoje poslove. U dogovoru s radnikom moguća je promjena posla bez smanjenja plaće ili promjena mjesta rada zbog razdvajanja počinitelja i žrtve. Organizacijska mjera može biti oslobođenje radnika obveze da radi u noćnoj smjeni ako je taj raspored rada uočen kao okolnost koja je pridonijela maltretiranju. Primjerena reakcija poslodavca može biti i provjera opravdanosti radne norme zbog smanjenja napora na radu i sl.

Propusti li reagirati poslodavac, radnik koji je žrtva maltretiranja može u sudskom postupku štititi svoja prava osobnosti na dostojanstvo te na tjelesno i duševno zdravlje ako trpi štetne posljedice čiji intenzitet opravdava takvu zaštitu. ${ }^{54}$ Također, radnik može posegnuti za pravom da odbije raditi i napusti mjesto rada (čl. 69., st. 4. ZZR-a), pri čemu nije važno postojanje opasnosti za "život". Naime, navedena odredba ZZR-a nije usklađena s Direktivom 89/391/EEZ koja je jače pravne snage. Slijedom Direktive radnik se koristi pravom da odbije raditi i napusti mjesto rada „u slučaju ozbiljne, neposredne i neizbježne opasnosti“ (čl. 8., st. 4.). Dakle, radnik ne mora trpjeti maltretiranje na radu sve do mjere kada mu to loše neželjeno ponašanje ugrožava „Život i zdravlje“, već se treba pozvati na odredbu Direktive koja je dovoljno jasna i bezuvjetna da bi mogla imati izravan učinak.
Određene obveze poslodavaca proizlaze iz ZR-a te antidiskriminacijskih zakona, ali su ograničenog dosega, budući da se odnose isključivo na neželjena ponašanja koja predstavljaju diskriminaciju. ${ }^{55}$ Posebnosti postupka zaštite dostojanstva radnika propisane su u članku 134. ZR-a. Postupak i mjere zaštite dostojanstva radnika od uznemiravanja i spolnog uznemiravanja uređuju se posebnim zakonom, kolektivnim ugovorom, sporazumom sklopljenim između radničkog vijeća i poslodavca ili pravilnikom o radu ${ }^{56}$. Poslodavac koji zapošljava najmanje dvadeset radnika dužan je imenovati osobu koja je osim njega ovlaštena primati i rješavati pritužbe u vezi sa zaštitom dostojanstva radnika. Poslodavac ili posebno ovlaštena osoba dužna je, u roku utvrđenom kolektivnim ugovorom, sporazumom sklopljenim između radničkog vijeća i poslodavca ili pravilnikom o radu, a najkasnije u roku od osam dana od dostave pritužbe, ispitati pritužbu i poduzeti sve potrebne mjere primjerene pojedinom slučaju zbog sprečavanja nastavka uznemiravanja ili spolnog uznemiravanja ako utvrdi da ono postoji.

Ako poslodavac u propisanom roku ne poduzme mjere za sprečavanje uznemiravanja ili spolnog uznemiravanja ili ako su mjere koje je poduzeo očito neprimjerene, radnik koji je uznemiravan ili spolno uznemiravan ima pravo prekinuti rad dok mu se ne osigura zaštita, pod uvjetom da je u daljnjem roku od osam dana zatražio zaštitu pred nadležnim sudom. ${ }^{57}$ Međutim, ako postoje okolnosti zbog kojih nije opravdano očekivati da će poslodavac zaštititi dostojanstvo radnika, radnik nije dužan dostaviti pritužbu poslodavcu i ima pravo prekinuti rad, pod uvjetom da je zatražio zaštitu pred nadležnim sudom i o tome obavijestio poslodavca u roku od osam dana od dana prekida rada. Za vrijeme prekida rada radnik ima pravo na naknadu plaće u iznosu plaće koju bi ostvario da je radio. Ako je pravomoćnom sudskom odlukom utvrđeno da nije povrijeđeno dostojanstvo radnika, poslodavac može zahtijevati povrat isplaćene naknade. ${ }^{58}$ Svi podaci utvrđeni u postupku zaštite dostojanstva radnika su tajni. Ponašanje radnika koje predstavlja uznemiravanje ili spolno uznemiravanje predstavlja povredu obveze iz radnog odnosa. Protivljenje radnika postupanju koje predstavlja uznemiravanje ili spolno uznemiravanje ne predstavlja povredu obveze iz radnog odnosa niti smije biti razlog za diskriminaciju. 
Upravne mjere propisane su člankom 226. ZR-a. U provedbi inspekcijskog nadzora u području rada inspektor će usmenim rješenjem u zapisniku poslodavcu narediti da u ostavljenom roku imenuje osobu koja je osim njega ovlaštena primati i rješavati pritužbe u vezi sa zaštitom dostojanstva radnika. Člankom 228. ZR-a propisan je teži prekršaj za koji će se kazniti poslodavac ako s podacima utvrđenim u postupku zaštite dostojanstva radnika ne postupa kao s tajnima.

Na kraju, radniku preostaje zaštita u kaznenom postupku. ${ }^{59}$

\section{ZAKLJUČAK}

Slijedom obilja literature o antidiskriminacijskom zakonodavstvu i pravnoj stečevini EU-a iz koje proizlazi, Hrvatskom se proširila percepcija da poslodavac treba štititi dostojanstvo, zdravlje i sigurnost radnika isključivo od uznemiravanja i spolnog uznemiravanja, kao zabranjenih oblika diskriminacije. Međutim, iz propisa o zaštiti na radu, osobito ZZR-a i Pravilnika o izradi procjene rizika, proizlaze nedvosmislene obveze poslodavca da štiti radnike od svih psihosocijalnih rizika na radu i u vezi s radom. $U$ dosegu tih obveza je i rizik od maltretiranja (mobbing, bullying) na radu i u vezi s radom.

Građanskopravnu i kaznenopravnu zaštitu kojom radnik može postići zaštitu prava osobnosti na dostojanstvo te na tjelesno i duševno zdravlje, a u ulozi tužitelja usmjerava je protiv poslodavca, odgovorna osoba kod poslodavca može predusresti proaktivnim preventivnim djelovanjima. Slijedom navedenog u interesu je poslodavaca da pojam maltretiranje iz Pravilnika o izradi procjene rizika tumači široko i da u postupku procjene rizika jednaku pozornost usmjeri na sve sastavnice zdravlja na radu i u vezi s radom, tj. na tjelesnu, duševnu i socijalnu. To je jedini način kojim udovoljava obvezi da zaštiti radnika od svih rizika na radu i u vezi s radom, a u pitanju je obveza koje se poslodavac ne može osloboditi. Pozivanje na primjere poslova s malim rizicima neće osloboditi poslodavca odgovornosti, jer je zakonska obveza da utvrdi i procijeni sve rizike, a ne da "mali“ rizik nekog posla tek prepiše iz Pravilnika kao gotovo rješenje.

\section{LITERATURA}

Charter of Fundamental Rights of the European Union (SL C 83, 30.3.2010.)

Constitution of the World Health Organization, dostupno na: http://apps.who.int/gb/bd/PDF/ bd47/EN/constitution-en.pdf?ua=1, pristupljeno: 25.6.2015.

Declaration concerning the Aims and Purposes of the International Labour Organisation, the 26th session of the ILO, Philadelphia, 10 May 1944, dostupno na: http://www.ilo.org/dyn/normlex/en/f?p=1000:62:0::NO:62:P62_LIST_ENTRIE_ID:2453907:NO\#declaration, pristupljeno: 25.6.2015.

Direktiva 2006/54/EZ Europskog parlamenta i Vijeća od 5. srpnja 2006. o provedbi načela jednakih mogućnosti i jednakog postupanja prema muškarcima i ženama u pitanjima zapošljavanja i rada (preinaka) (SL L 204, 26.7.2006.; posebno izdanje na hrvatskom jeziku, poglavlje 5., svezak 1.)

Direktiva Vijeća 2004/113/EZ od 13. prosinca 2004. o primjeni načela jednakog postupanja prema muškarcima i ženama u pristupu i pružanju dobara i usluga (SL L 373, 21.12.2004.; posebno izdanje na hrvatskom jeziku, poglavlje 5., svezak 1.)

Direktiva Vijeća 2000/78/EZ od 27. studenoga 2000. o uspostavi općeg okvira za jednako postupanje pri zapošljavanju i obavljanju zanimanja (SL L 303, 2.12.2000.; posebno izdanje na hrvatskom jeziku, poglavlje 5., svezak 1.)

Direktiva Vijeća 2000/43/EZ od 29. lipnja 2000. o provedbi načela jednakog postupanja prema osobama bez obzira na njihovo rasno ili etničko podrijetlo (SL L 180, 19.7.2000.; posebno izdanje na hrvatskom jeziku, poglavlje 20., svezak 1.)

Direktiva Vijeća 89/391/EEZ od 12. lipnja 1989. o uvođenju mjera za poticanje poboljšanja sigurnosti i zaštite zdravlja radnika na radu (SL L 183, 29. 6. 1989.; posebno izdanje na hrvatskom jeziku, poglavlje 5., svezak 4.) 
Državno odvjetništvo Republike Hrvatske, Priopćenja županijskih DO, Priopćenje Općinskog državnog odvjetništva u Sisku, dostupno na: http://www.dorh.hr/sisa09062015, pristupljeno: 25.6.2015.

ESLJP, 5856/72 od 25. 4. 1978., Tyrer/The United Kingdom

Eurofound: Physical and psychological violence at the workplace, Publication Office of the European Union, Luxembourg, 2013.

European Agency for Safety and Health at Work: Bullying at work, FACTS 23, 2002., dostupno na: https://osha.europa.eu/en/tools-andpublications/publications/factsheets/23/view, pristupljeno: 25.6.2015.

European framework agreement on harassment and violence at work, Brussels, 26. 4. 2007., dostupno na: http://www.etuc.org/framework-agreement-harassment-and-violencework, pristupljeno: 27.6.2015.

European Parliament resolution of 15 December 2011 on the mid-term review of the European strategy 2007 - 2012 on health and safety at work (2011/2147/(INI)), P/_TA(2011)0589, točka 92., dostupno na: http://www.europarl.europa. eu/sides/getDoc. do type $=$ TA \& reference $=$ P7 TA - 2011 - 0589 \& I a n g u a ge $=E N \&$ ring =A7-2011-0409, pristupljeno: 15.6.2015.

European Social Charter (revised), CETS No. 163, dostupno na: http://conventions.coe.int/ treaty/en/Treaties/Html/163.htm, pristupljeno: 25.6.2015.

Explanations relating to the Charter of fundamental rights (SL C 303, 14.12.2007.).

Gjuran-Coha, A. i Bosnar-Valković, B.: Lingvistička analiza medicinskoga diskursa, JAHR - European Journal of Bioethics, 4, 2013., 7, pp. 107-128.

Jacobson, N.: Dignity and health - A review, Social Science and Medicine, 64, 2007., pp. 292-302.

Kazneni zakon, N.N., br. 15/11., 144/12., 56/15. i 61/15.
Konvencija 155 - Konvencija o sigurnosti i zaštiti zdravlja na radu i o radnom okruženju, N.N. - Međunarodni ugovori, br. 11/03.

Mann, J. M., Gostin, L., Gruskin, S. et al.: Health and Human Rights, Health and Human Rights, 1, 1994., 1, pp. 6-23.

Međunarodni pakt o ekonomskim, socijalnim i kulturnim pravima, Službeni list SFRJ, br. 7/91.

Međunarodni pakt o građanskim i političkim pravima, Službeni list SFRJ, br. 7/91.

Numhauser-Henning, A. i Laulom, S.: Harassment related to Sex and Sexual Harassment Law in 33 European Countries: Discrimination versus Dignity, European Commission: Directorate-General for Justice, 2012.

Odluka o objavljivanju mnogostranih međunarodnih ugovora kojih je Republika Hrvatska stranka na temelju notifikacija o sukcesiji, N.N. - Međunarodni ugovori, br. 12/93.

Opća deklaracija o ljudskim pravima, N.N. Međunarodni ugovori, br. 12/09.

Pravilnik o izradi procjene rizika, N.N., br. 112/14.

Republika Hrvatska, Pravobraniteljica za ravnopravnost spolova: Izvješće o radu za 2012., ožujak 2013., dostupno na: http://www.prs.hr/ attachments/article/633/IZVJESCE2012web.pdf, pristupljeno: 25.6.2015.

Sud EU, C-507/12 od 19. 6. 2014., Jessy Saint Prix/Secretary of State for Work and Pensions, ECLI:EU:C:2014:2007

Sud EU, C-176/12 od 15. 1. 2014., Association de médiation sociale/Union locale des syndicats CGT, Hichem Laboubi, Union départementale CGT des Bouches-du-Rhône, Confédération générale du travail (CGT), ECLI:EU:C:2014:2ECR

Sud EU, C-282/10 od 24. 1. 2012., Maribel Dominguez/Centre informatique du Centre Ouest Atlantique and Préfet de la région Centre, ECLI:EU:C:2012:33

Sud EU, C-36/02 od 14. 10. 2004., Omega Spielhallen- und Automatenaufstellungs- $\mathrm{GmbH} /$ Oberbürgermeisterin der Bundesstadt Bonn, ECLI:EU:C:2004:614 
Sud EU, spojeni predmeti C-397/01 do C-403/01 od 5. 10. 2004., Bernhard Pfeiffer (C397/01), Wilhelm Roith (C-398/01), Albert Süß (C-399/01), Michael Winter (C-400/01), Klaus Nestvogel (C-401/01), Roswitha Zeller (C402/01) and Matthias Döbele (C-403/01)/Deutsches Rotes Kreuz, Kreisverband Waldshut eV., ECLI:EU:C:2004:584

Sud EU, C-37/00 od 27. 2. 2002., Herbert Weber/Universal Ogden Services Ltd, ECLI:EU:C:2002:122

Sud EU, C-84/94 od 12. 11. 1996., United Kingdom of Great Britain and Northern Ireland/Council of the European Union, ECLI:EU:C:1996:431

Sud EU, C-13/94 od 30. 4. 1996., P./S. and Cornwall County Council, ECLI:EU:C:1996:170

Sud EU, C-6/90 and C-9/90 od 19. 11. 1991., Andrea Francovich and Danila Bonifaci and others/Italian Republic, ECLI:EU:C:1991:428

Sud EU, C-66/85 od 3. 7. 1986., Deborah Lawrie-Blum/Land Baden-Württenberg, ECLI:EU:C:1986:284

Treaty on European Union (consolidated version 2012); (SL C 326, 26.10.2012.)

United Nations, Economic and Social Council, Committee on Economic, Social and Cultural Rights: Right to just and favourable conditions of work (article 7 of the International Covenant on Economic, Social and Cultural Rights), E/C.12/54/R.2, Fifty-fourth session, 23 February - 6 March 2015, dostupno na: http://www. ohchr.org/EN/HRBodies/CESCR/Pages/Discussion2015.aspx, pristupljeno: 25.6.2015.

Ustav Republike Hrvatske, N.N., br. 56/90., 135/97., 113/00., 28/01., 76/10. i 5/14.

USRH, U-I-448/2009, U-I-602/2009, U-I1710/2009, U-I-18153/2009, U-I-5813/2010, U-I-2871/2011 od 19. srpnja 2012.
USRH, U-I-4405/2013 i U-II-3222/2014 od 31. ožujka 2015.

USRH, U-III-1437/2007 od 23. travnja 2008.

VSRH, Revr 1253/2012-3 od 4. 2. 2014.

VSRH, Revr 685/2012-2 od 19. 3. 2013.

VSRH, Revr 816/2011-2 od 5. 3. 2013.

VSRH, Revr 1189/2011-2 od 11. 4. 2012.

VSRH, Revr 732/2011-2 od 26. 10. 2011.

VSRH, Revr 1648/2009-2 od 2. 3. 2011.

VSRH, 766/2009-2 Od 9. 9. 2009.

VSRH, Revr 32/2008-2 od 16. 4. 2008.

VSRH, Revr 219/2002-2 od 28. 3. 2002.

Wynne, R., De Broeck, V., Vandenbroek, K. et al.: Promoting mental health in the workplace - Guidance to implementing a comprehensive approach, European Commission, Employment, Social Affairs and Inclusion, November 2014, dostupno na: http://ec.europa.eu/social/ main.jsp?catld=716\&langld=en, pristupljeno: 15.6.2015.

Zakon o obveznim odnosima, N.N., br. 35/05., 41/08. i 125/11.

Zakon o radu, N.N., br. 93/14.

Zakon o ravnopravnosti spolova, N.N., br. 82/08.

Zakon o suzbijanju diskriminacije, N.N., br. 85/08. i 112/12.

Zakon o zaštiti na radu, N.N., br. 71/14., 118/14. i 154/14.

Zakon o životnom partnerstvu osoba istog spola, N.N., br. 92/14. 
${ }^{1}$ Zakon o zaštiti na radu, N.N., br. 71/14., 118/14. i 154/14.

${ }^{2}$ Pravilnik o izradi procjene rizika, N.N., br. 112/14.

${ }^{3}$ Zakon o radu, N.N., br. 93/14.

${ }^{4}$ Opća deklaracija o ljudskim pravima, N.N. - Međunarodni ugovori, br. 12/09.

${ }^{5}$ Međunarodni pakt o građanskim i političkim pravima (SI. list SFRJ, br. 7/91.); Međunarodni pakt o ekonomskim, socijalnim i kulturnim pravima (SI. list SFRJ, br. 7/91.). Vidjeti također Odluku o objavljivanju mnogostranih međunarodnih ugovora kojih je Republika Hrvatska stranka na temelju notifikacija o sukcesiji (N.N. - Međunarodni ugovori, br. 12/93.). Neslužbeni prijevod ovih međunarodnih ugovora na hrvatski jezik dostupan je na internetskoj stranici Ureda Vlade Republike Hrvatske za ljudska prava i prava nacionalnih manjina, http://www.uljppnm.vlada.hr/index.php?option=com_content\& view $=$ article\&id $=26 \&$ Itemid $=70$ (25.6.2015.)

${ }^{6}$ Odbor za ekonomska, socijalna i kulturna prava upravo provodi raspravu o nacrtu Općeg komentara članka 7. Međunarodnog pakta o ekonomskim, socijalnim i kulturnim pravima u kojem upućuje na vezu s Konvencijom 155 Međunarodne organizacije rada, kao i na potrebu ravnopravno štititi tjelesno i duševno zdravlje radnika, zabraniti uznemiravanje i spolno uznemiravanje te sve oblike diskriminacije na radu i u vezi s radom i zapošljavanjem. Right to just and favourable conditions of work (article 7 of the International Covenant on Economic, Social and Cultural Rights), Economic and Social Council: Committee on Economic, Social and Cultural Rights, E/C.12/54/R.2, Fifty-fourth session, 23 February - 6 March 2015, http://www.ohchr. org/EN/HRBodies/CESCR/Pages/Discussion2015.aspx (25.6.2015.)

7 "II. Believing that experience has fully demonstrated the truth of the statement in the Constitution of the International Labour Organisation that lasting peace can be established only if it is based on social justice, the Conference affirms that: (a) all human beings, irrespective of race, creed or sex, have the right to pursue both their material well-being and their spiritual development in conditions of freedom and dignity, of economic security and equal opportunity; ...". Vlastiti prijevod: II. Uvjereni da je iskustvo pokazalo osnovanost izjave koju sadrži Ustav Međunarodne organizacije rada i prema kojoj trajan mir može biti ostvaren samo na osnovi socijalne pravde, Skupština potvrđuje da: (a) sva ljudska bića, bilo koje rase, vjere ili spola, imaju pravo zahtijevati svoj materijalni napredak i duhovni razvoj u slobodi i dostojanstvu, u ekonomskoj sigurnosti i s jednakim mogućnostima; .... Declaration concerning the Aims and Purposes of the International Labour Organisation, adopted at the 26th session of the ILO, Philadelphia, 10 May 1944, http://www.ilo.org/dyn/normlex/en/f?p=1000:62:0::NO:62:P62_LIST_ENTRIE_ID:2453907:NO\#declaration (25.6.2015.)

${ }^{8}$ Constitution of the World Health Organization, http://apps.who.int/gb/bd/PDF/bd47/EN/constitution-en.pdf?ua=1 (25.6.2015.)

${ }^{9}$ European Social Charter (revised), CETS No. 163, http://conventions.coe.int/treaty/en/Treaties/Html/163.htm (25.6.2015.)

${ }^{10}$ Charter of Fundamental Rights of the European Union (SL C 83, 30.3.2010.)

11 Članak 6., stavak 1. Ugovora o Europskoj uniji. Treaty on European Union (consolidated version 2012); (SL C 326, 26.10.2012.). Prijevod Lisabonskog ugovora (Ugovor o Europskoj uniji, Ugovor o funkcioniranju Europske unije i Povelja temeljnih prava Europske unije) na hrvatski jezik dostupan je na internetskoj stranici Ministarstva vanjskih i europskih poslova, http://www.mvep.hr/custompages/static/hrv/files/pregovori/111221-lisabonski-prociscena.pdf (25.6.2015.)

12 "Ova Povelja potvrđuje, uz dužno poštovanje nadležnosti i zadataka Unije te načela supsidijarnosti, prava koja proistječu osobito iz ustavnih tradicija i međunarodnih obveza zajedničkih državama članicama, iz Europske konvencije za zaštitu ljudskih prava i temeljnih sloboda, iz Socijalne povelje koju su usvojile Unija i Vijeće Europe te iz prakse Suda Europske unije i Europskoga suda za ljudska prava. U tom kontekstu Povelju će tumačiti sudovi Unije i država članica, uzimajući u obzir objašnjenja pripremljena pod vodstvom predsjedništva Konvencije koje je sastavilo Povelju i ažurirana pod odgovornošću predsjedništva Europske konvencije."

${ }^{13}$ Explanations relating to the Charter of fundamental rights (SL C 303, 14.12.2007.)

14 Prije stupanja na snagu Povelje EU-a Sud EU-a štitio je dostojanstvo pravnim shvaćanjem da je taj koncept opće načelo prava EU-a. Vidjeti npr. Sud EU, C-36/02 od 14. 10. 2004., Omega Spielhallen- und Automatenaufstellungs-GmbH / Oberbürgermeisterin der Bundesstadt Bonn, ECLI:EU:C:2004:614

15 Direktiva Vijeća 89/391/EEZ od 12. lipnja 1989. o uvođenju mjera za poticanje poboljšanja sigurnosti i zaštite zdravlja radnika na radu (SL L 183, 29. 6. 1989.; posebno izdanje na hrvatskom jeziku, poglavlje 5., svezak 4.). Ažuran pregled svih direktiva koje su na snazi dostupan je u bazi EUR-Lex u registarskom području 05.20.20.10 Health and Safety, http://eur-lex.europa.eu/search.html?CC_1_CODED=05\&CC_4_ CODED=05202010\&name=browse-by:legislation-in-force\&CC_2_CODED=0520\&displayProfile=allRelAllConsDocProfile\&qid=1427211746387\& CC_3_CODED=052020\&type=named (25.6.2015.)

${ }^{16}$ Izravno pozivanje na odredbe Povelje EU-a u sporovima između pojedinaca još nije moguće. Moguće je pozivanje na odredbe sekundarnog prava EU-a kojima se preciziraju odredbe Povelje ako te odredbe sekundarnog prava ispunjavaju uvjete za izravni učinak. Za sada Sud EU-a smatra da je moguća izravna primjena načela nediskriminacije iz članka 21., stavka 1. Povelje EU-a. Pobliže vidjeti u presudi Sud EU, C-176/12 od 15. 1. 2014., Association de médiation sociale/Union locale des syndicats CGT, Hichem Laboubi, Union départementale CGT des Bouches-du-Rhône, Confédération générale du travail (CGT), ECLI:EU:C:2014:2ECR.

${ }_{17}$ Sud EU, C-6/90 and C-9/90 od 19. 11. 1991., Andrea Francovich and Danila Bonifaci and others/Italian Republic, ECLI:EU:C:1991:428.

${ }^{18}$ Direktiva 2006/54/EZ Europskog parlamenta i Vijeća od 5. srpnja 2006. o provedbi načela jednakih mogućnosti i jednakog postupanja prema muškarcima i ženama u pitanjima zapošljavanja i rada (preinaka); (SL L 204, 26.7.2006.; posebno izdanje na hrvatskom jeziku, poglavlje 5., svezak 1.); Direktiva Vijeća 2004/113/EZ od 13. prosinca 2004. o primjeni načela jednakog postupanja prema muškarcima i ženama u pristupu i pružanju dobara i usluga (SL L 373, 21.12.2004.; posebno izdanje na hrvatskom jeziku, poglavlje 5., svezak 1.); Direktiva Vijeća 2000/78/EZ od 27. studenoga 2000. o uspostavi općeg okvira za jednako postupanje pri zapošljavanju i obavljanju zanimanja (SL L 303, 2.12.2000.; posebno izdanje na hrvatskom jeziku, poglavlje 5., svezak 1.); Direktiva Vijeća 2000/43/EZ od 29. lipnja 2000. o provedbi načela jednakog postupanja prema osobama bez obzira na njihovo rasno ili etničko porijeklo (SL L 180, 19.7.2000.; posebno izdanje na hrvatskom jeziku, poglavlje 20., svezak 1.). U domaći pravni poredak prenesene su Zakonom o suzbijanju diskriminacije.

${ }^{19}$ European framework agreement on harassment and violence at work, Brussels, 26.4.2007., http://www.etuc.org/framework-agreement-harassment-and-violence-work (27.6.2015.)

${ }^{20}$ Treba biti vrlo oprezan kada su u pitanju autonomni te neobvezujući izvori prava EU-a (soft-law), kao što je to navedeni Sporazum, ili pak tumačenja odnosno smjernice institucija EU-a za primjenu određenih pravnih akata EU-a. Primjerice, Sporazum ne obvezuje države članice da usklade svoje pravne poretke s uglavcima Sporazuma. Europska komisija nema obvezu ni ovlast pratiti primjenu i ostvarivanje ugovorenih obveza u državama članicama te protiv njih poduzimati mjere propisane osnivačkim ugovorima ako utvrdi da uopće nije došlo do primjene ili da je u pitanju nepotpuna primjena. Međutim, treba računati na to da će se Sud Europske unije (Sud EU-a) služiti tim izvorom prava ravnopravno kao i s pravno obvezujućim izvorima (hard-law) uvijek kada tumači tako važna prava kao što su temeljna socijalna prava radnika EU-a. Sud EU-a crpi inspiraciju iz svih izvora te nije opterećen njihovom (ne)obvezujućom pravnom naravi. Iz izvora koji nisu pravno obvezujući neće crpiti dokaze o pravu ili obvezi pravnog subjekta, već vrednote, načela, iskazanu ugovornu volju i njezinu namjeru, svrhu i ciljeve kojima trebaju poslužiti te ostale kontekstualne odrednice kojima obrazlaže svoja pravna shvaćanja i osnažuje njihovu uvjerljivost. Na taj način Sud EU-a sugerira nedostajući normativni sadržaj prava odnosno obveze koji je posljedica nedorečenosti odredaba pravnog akta. 
${ }^{21}$ Ustav Republike Hrvatske, N.N., br. 56/90., 135/97., 113/00., 28/01., 76/10. i 5/14.

${ }^{22}$ USRH, U-I-448/2009, U-I-602/2009, U-I-1710/2009, U-I-18153/2009, U-I-5813/2010, U-I-2871/2011 od 19. srpnja 2012.

${ }^{23}$ USRH, U-I-4405/2013 i U-II-3222/2014 od 31. ožujka 2015.

24 "Nabavkom novog vozila s dizalicom i zapošljavanjem novog vozača, a da tužitelja tuženik nije ni pokušao osposobiti za dizaličara, tuženik je trajno tužitelja lišio obavljanja njegovog osnovnog posla - vozača teretnog vozila, za koje poslove je prvenstveno i sklopio ugovor o radu, degradirajući ga u NKV radnika na poslovima pripomoći radnicima u građevinarstvu i to trajno. Tuženik se zbog izmijenjenih uvjeta morao poslužiti institutom otkaza s ponudom izmijenjenog ugovora, jer mu ni sadržaj ugovora o radu ni odredbe pravilnika kao ni zakona nisu dopuštale u datoj situaciji mijenjanje ugovora na štetu tužitelja, a posebice odredaba st. 2. čl. 7. ZR kojom se štiti pravo i dostojanstvo radnika. Stoga su sudovi s osnovom zaključili da je u konkretnom slučaju tuženik sam izazvao sporno tužiteljevo ponašanje, budući mu tuženik nije omogućio formalni način protivljenja takvom nepravilnom postupanju, pa u tim okolnostima ponašanje tužitelja nema značenje osobito teške povrede obveze iz radnog odnosa zbog kojeg nastavak radnog odnosa nije moguć jer tužitelj štiteći svoja prava i dostojanstvo osnovano je odbio trajno vršenje pomoćnih poslova NKV radnika." VSRH, Revr 32/2008-2 od 16. 4. 2008.

"Naime, nalozima za rad tužitelji nisu premješteni s radnog mjesta za koje su sklopili ugovor o radu na drugo radno mjesto, već su tim nalozima samo upućeni na drugo mjesto obavljanja rada, uvijek zadržavši radno mjesto vozača teretnog vozila. Takva mogućnost promjene mjesta obavljanja rada upravo je ugovorena među strankama čl. 2. Ugovora o radu sklopljenih među strankama. Prema pravnom shvaćanju Vrhovnog suda Republike Hrvatske kada su nalozi za rad doneseni u skladu sa sklopljenim ugovorima o radu, nema govora o tome da bi takvim postupanjem tuženika tužitelji bili uznemiravani i time bilo narušeno njihovo dostojanstvo kao radnika, zaštićeno čl. 30. (ranije 22.a.) ZR. Ovo posebno kada se ima u vidu činjenica da su nalozi za rad tužitelja u drugoj poslovnoj jedinici uslijedili iz poslovno opravdanih razloga, obzirom da je u Sektoru F1 gdje su tužitelji prije radili došlo do smanjenja opsega poslova, a time i smanjenja potrebe za radnicima, a naprotiv u poslovnoj jedinici V. u istom razdoblju došlo do znatnog povećanja prometa, a time i povećane potrebe za radnicima. Stoga je upućivanje tužitelja u tu poslovnu jedinicu bilo poslovno opravdano, a ne šikanozno postupanje prema njima." VSRH, 766/2009-2 od 9. 9. 2009.

${ }^{25}$ Zakon o suzbijanju diskriminacije, N.N., br. 85/08. i 112/12.

${ }^{26}$ Kazneni zakon, N.N., br. 15/11., 144/12., 56/15. i 61/15.

${ }^{27} \mathrm{Na}$ zaštitu dostojanstva na radu moguća je analogna primjena pravnog shvaćanja Europskog suda za ljudska prava u predmetu Tyrer v. The United Kingdom prema kojem je dostojanstvo osobe povrijeđeno i onda kada nije ponižena u javnosti, ali je ponižena pred samom sobom odnosno u vlastitim očima. ESLJP, 5856/72 od 25. 4. 1978., Tyrer/The United Kingdom.

${ }^{28}$ Zakon o ravnopravnosti spolova, N.N., br. 82/08.

${ }^{29}$ Zakon o životnom partnerstvu osoba istog spola, N.N., br. 92/14.

${ }^{30}$ Zakon o obveznim odnosima, N.N., br. 35/05., 41/08. i 125/11.

${ }^{31}$ USRH, U-III-1437/2007 od 23. travnja 2008.

32 "Zlostavljanje (uznemiravanje) koje podvodimo pod pojam mobinga ne mora biti uzrokovano niti jednim od navedenih temelja diskriminacije, ono može biti posljedica individualnih ili grupnih obrazaca ponašanja. Međutim, takve osnove uznemiravanja ne uživaju sudsku zaštitu prema odredbama Zakona o radu. Imajući u vidu da radniku pripada pravo na primjerenu zaštitu na radnom mjestu, a na poslodavcu leže obveze zaštite dostojanstva radnika te radnik uživa zaštitu ne samo od poslodavca nego i od drugih nadređenih, suradnika i osoba s kojima redovito dolazi u doticaj u obavljanju poslova svako uznemiravanje radnika od tih osoba predstavlja povredu radne obveze. Prema tome kada se utvrdi da je došlo do takvog zlostavljanja (uznemiravanja) na radnom mjestu te ukoliko težina povrede i okolnosti slučaja to opravdavaju, radnik ima pravo na naknadu štete zbog povrede prava iz radnog odnosa u kojem slučaju se primjenjuje odredba Zakona o obveznim odnosima, kao opći propis obveznog prava. Na temelju utvrđenog činjeničnog stanja nižestupanjski sudovi pravilno nadalje zaključuju da je tužiteljica u spornom razdoblju bila zlostavljana i uznemirena od strane nadređene joj osobe, koje ponašanje ima obilježje mobinga. Međutim tužiteljica nije dokazala da je zbog opisanog postupanja direktorice trpjela objektivizirane posljedice u odnosu na njezino ranije zdravstveno stanje koje se moglo podvesti pod priznate oblike nematerijalne štete kao što su fizičke boli, strah odnosno duševne boli koje su rezultat smanjenja životne aktivnosti. Pravilan je zaključak nižestupanjskih sudova da je tužiteljica trpjela duševne boli zbog povrede ugleda i časti, kao posljedice negativnog i neprimjerenog ponašanja i postupanja nadređene I. F., pa vodeći pri tome računa o pravu na naknadu nematerijalne štete za pretrpljene duševne boli zbog povrede časti i ugleda propisane čl. 200. ZOO, pravilno su postupili kada su dosudili naknadu nematerijalne štete za ovaj vid štete u iznosu 10.000,00 kn." VSRH, Revr 1253/2012-3 od 4. 2.2014.

${ }^{33}$ Pobliže o odnosima dostojanstva i zdravlja vidjeti primjerice u: Jacobson, N.: Dignity and health: A review, Social Science \& Medicine, 64, 2007, pp. 292-302; Mann, J. M., Gostin, L., Gruskin, S. et al., Health and Human Rights, Health and Human Rights, vol. 1, $1994 .$, br. 1, pp. 6-23.

${ }^{34}$ Rezultati su dostupni na internetskim stranicama Eurofound: EurWORK - European Observatory of Working Life, u području Health and wellbeing at work, http://www.eurofound.europa.eu/health-and-well-being-at-work (15.6.2015.).

${ }_{35}$ Pobliže vidjeti u Eurofound: Physical and psychological violence at the workplace, Publication Office of the European Union, Luxembourg, 2013., p. 7-8.

${ }^{36}$ Pobliže vidjeti komparativnu studiju koja obuhvaća i Hrvatsko zakonodavstvo: Numhauser-Henning, A. i Laulom, S.: Harassment related to Sex and Sexual Harassment Law in 33 European Countries: Discrimination versus Dignity, European Commission: Directorate-General for Justice, 2012.

${ }^{37}$ European Parliament resolution of 15 December 2011 on the mid-term review of the European strategy 2007 - 2012 on health and safety at work (2011/2147/(INI)), P/_TA(2011)0589, točka 92., http://www.europarl.europa.eu/sides/getDoc.do?type=TA\&reference=P7-TA-2011-0589\&language=EN \&ring=A7-2011-0409 (15.6.2015.).

${ }^{38}$ Rezolucija nije prevedena na hrvatski jezik. U prijevodu na njemački jezik korišten je pojam mobbing, u francuskoj verziji harcèlement moral, španjolskoj acoso moral, slovenskoj moralno nadlegovanje, švedskoj mobbning, a u talijanskoj vessazioni morali (mobbing).

${ }^{39}$ Wynne, R., De Broeck, V., Vandenbroek, K. et al.: Promoting mental health in the workplace: Guidance to implementing a comprehensive approach, European Commission: Employment, Social Affairs \& Inclusion, November 2014, p. 5, http://ec.europa.eu/social/main.jsp?catld=716\&langld=en (15.6.2015.).

${ }^{40}$ Bullying at work, FACTS 23, European Agency for Safety and Health at Work, 2002., https://osha.europa.eu/en/tools-and-publications/publications/factsheets/23/view (15.6.2015.) Engleski pojam bullying u njemačkom izdanju preveden je s mobbing, u francuskom harcèlement moral, švedskom mobbning, slovenskom ustrahovanje, talijanskom mobbing te španjolskom acoso moral.

${ }^{41}$ Prijevod na njemački jezik je belästigung, na francuski harcèlement, švedski trakasserier, slovenski nadlegovanje, talijanski molestie te na španjolski acoso.

${ }^{42}$ Kako je riječ o posuđenici, pojam „mobing“ trebalo bi pisati "mobbing”, no najbolje rješenje bilo bi zamijeniti ga pojmom „zlostavljanje”, a još bolje "zlostavljanje na radu i u vezi s radom". Umjesto posuđenice "bullying" prihvatljivije bi bilo "zastrašivanje". Izgleda da bi uporaba pojma "maltretiranje" bila jezično prihvatljiva. Naime, Nives Opačić navodi: "Zlostavljanje i zlostavljači danas su se u hrvatskom, kao riječi, uglavnom potpuno povukli, što nipošto ne znači da njihove rabote više nema. Ima puno i previše, no ogrnula se u sve rasprostranjenije engleske izraze mobbing, bullying, bossying i slične -ingove. I te riječi imaju u jeziku izvorniku nešto drukčije značenje nego u jezicima koji su ih posudili, pa tako bullying, osim vršnjačkoga nasilja u školi, znači i zlostavljanje starijih, o čemu se u nas u tom kontekstu uopće ne govori. Mob u engl. znači fukara, svjetina, rulja, 
buntovno mnoštvo, klapa, banda i sl., a kao glagol napadati, pljačkati, galamiti, dodijavati kao rulja. Mobbing and rioting znači bučno okupljanje i narušavanje javnog reda, no u nas se mobbing ustaljuje za maltretiranje na poslu. Zanimljivo je da the mob znači gangstere, mafiju, a mob law zakon rulje; nasilje. Valjda nas cijeli taj koloplet tako neodoljivo podsjeća na prilike u hrvatskim tvrtkama kad mobbing vezujemo uz radno mjesto! Bossying bi se reklo da je ono nasilje koje nad zaposlenicima provodi gazda (boss). No, bossy znači sklon zapovijedanju općenito, nametanju svoje volje, što nije spolna odrednica, ali kao imenica bossy to jest: oštrokondža. Prije smo sve takve i slične pojave zvali jednostavno zlostavljanje ili maltretiranje, što je i značenjski mnogo prozirnije: zlostavljač je onaj koji s drugim postupa tako da mu nanosi zlo, koji ga stavlja u nezavidan, loš položaj. A to znači i maltretiranje (loše postupanje). No danas nam to očito više nije dovoljno (izražajno)." Izvor: Vijenac, 381, 9. listopada 2008., http://www.matica.hr/ vijenac/381/Zlo\%20-\%20iz\%20busije,\%20s\%20kraja\%20abecede/ (15.6.2015.)

${ }^{43}$ Porijeklo je iz francuskog jezika od mal (loše) i traiter (postupati). U njemačkom jeziku odgovara mu glagol malträtieren.

${ }^{44}$ Gjuran-Coha, A. i Bosnar-Valković, B.: Lingvistička analiza medicinskoga diskursa, JAHR - European Journal of Bioethics, vol. 4, 2013., br. 7, p. $122-123$.

${ }^{45}$ Primjerice, u vrijeme dok Povelja EU-a nije bila na snazi Sud je izrazio shvaćanje da je njegova obveza zaštititi dostojanstvo i slobode radnika. Sud EU, C-13/94 od 30. 4. 1996., P./S. and Cornwall County Council, ECLI:EU:C:1996:170.

${ }^{46}$ Sud EU, C-282/10 od 24. 1. 2012., Maribel Dominguez/Centre informatique du Centre Ouest Atlantique and Préfet de la région Centre, ECLI:EU:C:2012:33.

${ }^{47}$ Sud EU, C-37/00 od 27. 2. 2002., Herbert Weber/Universal Ogden Services Ltd, ECLI:EU:C:2002:122; Sud EU, spojeni predmeti C-397/01 do C-403/01 od 5. 10. 2004., Bernhard Pfeiffer (C-397/01), Wilhelm Roith (C-398/01), Albert Süß (C-399/01), Michael Winter (C-400/01), Klaus Nestvogel (C-401/01), Roswitha Zeller (C-402/01) and Matthias Döbele (C-403/01)/Deutsches Rotes Kreuz, Kreisverband Waldshut eV., ECLI:EU:C:2004:584.

${ }^{48}$ Sud EU, C-66/85 od 3. 7. 1986., Deborah Lawrie-Blum/Land Baden-Württenberg, ECLI:EU:C:1986:284; Sud EU, C-507/12 od 19. 6. 2014., Jessy Saint Prix/Secretary of State for Work and Pensions, ECLI:EU:C:2014:2007.

${ }^{49}$ Presuda se odnosi na članak 118.a Ugovora o Europskoj zajednici kojem sada odgovara članak 153. Ugovora o funkcioniranju EU-a. Sud EU, C-84/94 od 12. 11. 1996., United Kingdom of Great Britain and Northern Ireland/Council of the European Union, ECLI:EU:C:1996:431.

50 " U konkretnom slučaju riječ je o obavljanju poslova i zadataka iz ugovora o radu, pa u takvoj situaciji nije riječ o korištenju nadređenosti poslodavca i šikaniranju tužitelja kao radnika, već o potrebi poslodavca da organizira posao u skladu sa vrstom i prirodom tog posla, u skladu sa ugovorom o radu kojeg su stranke sklopile u okviru radnog mjesta prema dnevnim potrebama obavljanja poslova, a pri čemu tužitelj ničim nije šikaniran odnosno uznemiravan. Kako tužitelj nije dokazao da je šikaniran i uznemiravan od strane nadređenih to su nižestupanjski sudovi pravilno odbili zahtjev tužitelja za naknadu štete zbog povrede prava osobnosti primjenom odredbe čl. 221. ZPP-a, pa je bespredmetno ustrajavanje tužitelja na tvrdnji da je uznemiravan i šikaniran od strane tuženika." VSRH, Revr 685/2012-2 od 19. 3. 2013.

${ }^{51}$ Prije stupanja na snagu ZZR-a i Pravilnika o izradi procjene rizika pučka pravobraniteljica reagirala je na Nacrt novog Zakona o radu te upozorila ministra nadležnog za rad: "Naime, u praksi je često teško razlučiti koja ponašanja predstavljaju mobbing, kao zlostavljajuće ponašanje, a koja uznemiravanja koja su diskriminatorna, budući da mobbing ne treba biti utemeljen niti na jednoj diskriminacijskoj osnovi. Prema postojećim zakonskim odredbama, ali i prema ovom Nacrtu, ne pruža se zaštita od mobbinga, već isključivo zaštita od uznemiravanja i spolnog uznemiravanja kao oblika diskriminacije. Pri tome se poziva na posebni zakon, a to je Zakon o suzbijanju diskriminacije, koji za uznemiravanje traži postojanje neke od diskriminacijskih osnova, dok za mobbing to nije slučaj. Stoga pri normiranju mobbinga treba jasno napraviti razliku između uznemiravanja kao oblika diskriminacije kako ga definira ZSD i europsko antidriskiminacijsko pravo i koje mora biti povezano s nekom diskriminacijskom osnovom i mobbinga kod kojeg zlostavljačko ponašanje nije povezano niti uzrokovano nekom diskriminacijskom osnovom. Na koji način bi trebala izgledati zaštita od mobbinga te hoće li on biti reguliran odredbama novoga Zakona o radu ili posebnim zakonom o mobbingu, treba odlučiti nakon procjene prijedloga i argumenata stručne javnosti i svih zainteresiranih dionika." Izvor: Republika Hrvatska, Pučki pravobranitelj, broj: P.P.R.-01-11-381/13-01 od 22. studenoga 2013.

${ }^{52}$ Konvencija 155 - Konvencija o sigurnosti i zaštiti zdravlja na radu i o radnom okruženju (N.N. - Međunarodni ugovori, br. 11/03.). Definicija je navedena u članku 3. točki (e) i glasi: "izraz »zdravlje«, kad se odnosi na rad, ne označava samo izostanak bolesti ili nesposobnosti; on također uključuje tjelesne i duševne čimbenike koji utječu na zdravlje, a koji su u izravnoj vezi sa sigurnošću i higijenom na radu."

53 "Tuženik ističe, da je odluka o otkazu donesena u zakonito provedenom postupku, a s obzirom na utvrđenja suda, da je tuženik tvrtka koja se bavi održavanjem stambenih zgrada, te da je tužitelj obavljajući radove u jednoj zgradi došao u fizički sukob s jednim od suvlasnika zgrade, u koju se situaciju sam doveo nekorektnim ponašanjem, smatra da je opravdana odluka o izvanrednom otkazu. U predmetnom slučaju sudovi su ocijenili da ponašanje tužitelja, odnosno fizički sukob u koji se upustio kad se branio od napada suvlasnika zgrade, ne predstavlja naročito tešku povredu obveze iz radnog odnosa, upravo s obzirom na okolnosti u kojima se dogodio tj. tužitelj je bio napadnut a situaciju u kojoj se to dogodilo, suprotno navodima tuženika u reviziji i tijekom postupka, nije sam isprovocirao. Tuženik dakle kao poslodavac nije dokazao postojanje opravdanog razloga za otkaz u smislu odredbe čl. 112. ZR, pa budući da doista može tužitelja rasporediti ubuduće na rad u drugim zgradama koje održava, nema mjesta zaključku da nastavak radnog odnosa ne bi bio moguć." VSRH, Revr 219/2002-2 od 28. 3. 2002.

54 "Okolnost da je tuženik u konfliktnim situacijama do kojih je dolazilo kada su tužiteljice tražile od tuženika isplatu plaće i ostvarenje drugih prava iz radnog odnosa tuženik upućivao tužiteljicama neprimjerene riječi predstavlja ponašanje uvredljivog karaktera. Međutim, samo na temelju te okolnosti nije opravdano dosuditi tužiteljicama naknadu neimovinske štete koja se u slučaju povrede prava osobnosti na ugled, čast i dostojanstvo iznimno priznaje $\mathrm{i}$ to ako je ta povreda teška tako da je kod povrijeđenoga opravdano mogla izazvati osobito intenzivne duševne bolove, a što ovdje nije slučaj." VSRH, Revr 816/2011-2 od 5. 3. 2013.

${ }^{55}$ Neefikasnost ZR-a otkriva Izvješće o radu za 2012. Pravobraniteljice za ravnopravnost spolova. Republika Hrvatska, Pravobraniteljica za ravnopravnost spolova: Izvješće o radu za 2012., ožujak 2013., p. 33-36, http://www.prs.hr/attachments/article/633/IZVJESCE2012web.pdf (25.6.2015.).

56 "Neosnovano je pozivanje revidenta na shvaćanje ovoga suda izraženo u revizijskoj odluci broj Revr-716/04 od 2. ožujka 2005. da poslodavac nije ovlašten propisati svojim općim aktom koje je skrivljeno ponašanje radnika osobito teška povreda radne obveze, jer takovo ovlaštenje u odnosu na zaštitu dostojanstva radnika od uznemiravanja ili spolnog uznemiravanja proizlazi iz odredbe čl. 30. st. 3. ZR-a. Prema toj odredbi postupak i mjere zaštite dostojanstva radnika uređuju se kolektivnim ugovorom, sporazumom sklopljenim između Radničkog vijeća i poslodavca ili pravilnikom o radu. Jedna od takvih mjera može biti i otkaz ugovora o radu zbog povrede radne obveze uznemiravanjem i spolnim uznemiravanjem, pa u slučaju ako je poslodavac svojim pravilnikom odredio u kojem slučaju će se ta povreda smatrati osobito teškom povredom obveze iz radnog odnosa, takva odredba pravilnika ga obvezuje kod donošenja odluke o otkazu. Stoga je tuženik mogao dati tužitelju izvanredni otkaz samo pod uvjetima određenim spomenutom odredbom Pravilnika - da je riječ o slučaju ponovljenog uznemiravanja ili spolnog uznemiravanja ili da čin uznemiravanja ili spolnog uznemiravanja ima obilježja kaznenog djela." VSRH, Revr 732/2011-2 od 26. 10. 2011.

57 "Iz nalaza i mišljenja sudskog vještaka, kao i njegove dopune proizlazi da su psihički problemi tužitelja (anksiozno depresivni poremećaj) vezani isključivo uz radne probleme, da je osjećaj degradacije poniženja, osjećaj izoliranosti vezan uz premještaj na novo radno mjesto - poslovođa II i njegov nejednaki tretman u odnosu na ostale djelatnike u okviru istih ili sličnih poslova i radnih zadataka. Dakle, suprotno zaključku nižestupanjskih sudova u ovom postupku tužbenim zahtjevom tužitelj traži naknadu štete zbog povrede prava na jednako postupanje što znači zbog diskriminacije u smislu čl. 2. st. 1. ZR. Sudovi su stoga zbog pogrešnog pravnog pristupa smatrajući da povreda dostojanstva radnika i tzv. mobing predstavljaju "različite pojmove“ 
pogrešno primijenili pravila o teretu dokazivanja. Naime, u smislu čl. 6. ZR ako radnik u slučaju spora iznese činjenice koje opravdavaju sumnju da je poslodavac postupio protivno odredbama čl. 2. ZR na poslodavcu je teret dokazivanja da nije bilo diskriminacije, odnosno da je postupio u skladu s odredbama čl. 3. Zakona." VSRH, Revr 1648/2009-2 od 2. 3. 2011.

58 "Dakle, ZR propisuje sudsku zaštitu radnika u slučaju kada poslodavac nije poduzeo mjere kako bi spriječio uznemiravanje ili spolno uznemiravanje ili su poduzete mjere očito neprimjerene, pa nastavak rada u takvom radnom okruženju za radnika nije prihvatljiv. $U$ tom slučaju, radnik uslijed prekinutog rada na način propisan Zakonom, ostvaruje pravo na naknadu plaće do okončanja sudskog spora. Radi se dakle o situaciji kada je poslodavac teško povrijedio svoju obvezu iz ugovora o radu kršeći zakonsku obvezu zaštite dostojanstva radnika.

Treba međutim imati u vidu da prekidom rada radnik preuzima na sebe rizik da se u sudskom postupku utvrdi da poslodavac nije povrijedio obvezu te da je prekid bio neopravdan. S obzirom na to da nije moguće radni odnos ispunjavati unazad, radnik koji nije uspio u sporu radi zaštite dostojanstva, a primio je naknadu plaće, je dužan isplatiti poslodavcu novčani ekvivalent za neizvršeni rad i to upravo u visini bruto ugovorene plaće konkretnog radnika. Polazeći od utvrđenja da je tuženik prekinuo rad, a pravomoćno je odbijen njegov tužbeni zahtjev za zaštitu dostojanstva, proizlazi da je prekid rada bio neopravdan, pa je tuženik dužan ispuniti svoju ugovornu obvezu na način koji je jedino još moguć, dakle isplatom novčanog ekvivalenta nenovčane obveze iz ugovora o radu." VSRH, Revr 1189/2011-2 od 11. 4. 2012.

59 “Općinsko državno odvjetništvo u Sisku je podiglo optužnicu protiv hrvatskog državljanina (1949.) zbog počinjenja kaznenog djela zlostavljanja na radu iz članka 133. stavak 1. Kaznenog zakona. (9. 6. 2015.). Optužnicom se okrivljenika tereti da je od 16. svibnja do 14 . kolovoza 2014 . te od 29. rujna do 12. studenog 2014. u Kutini, kao direktor trgovačkog društva, zaposlenici u tom trgovačkom društvu rekao da od njega u startu ima žuti karton, da se pripazi da ne dobije i crveni karton, da se nije dobro ponašala i da nije vezala konja gdje gazda kaže, isključio ju je od obavljanja posla i zabranio joj da obavlja čak i niže plaćene poslove na koje ju je rasporedio bez ikakvog opravdanog razloga. Zaposlenica je svakodnevno dolazila na posao, no nije joj bilo dopušteno obavljati niti jedan zadatak iz opisa njenog radnog mjesta. Okrivljenik je naložio ostalim zaposlenicima da se od nje distanciraju i da s njom ne razgovaraju, a njoj je rekao da bez njegovog dopuštenja ne smije ni sa kim razgovarati. Tereti ga se da joj je naložio da tijekom radnog vremena smije samo dva puta otići na toalet te je naložio montiranje kamere usmjerene na njezin ured kako bi se nadziralo njeno kretanje. Zaposlenica se uslijed svega navedenog razboljela zbog čega je zatražila liječničku pomoć." Izvor: Državno odvjetništvo Republike Hrvatske, Priopćenja županijskih DO, Priopćenje Općinskog državnog odvjetništva u Sisku, http://www.dorh.hr/sisa09062015 (25.6.201

\section{PROTECTION OF DIGNITY AND HEALTH - PROTECTION FROM MISTREATMENT AT WORK}

SUMMARY: Reports published by Croatian state institutions and evidence furnished by the courts indicate that working conditions in Croatia do not meet the standards set out in the fundamental right of employees in the EU and Croatia to fair and legal working conditions that guarantee health, safety and dignity. This right is expressly stipulated in the EU Fundamental Rights Charter. Repeated proposal has been made in Croatia to pass a special act on mobbing, but the proposal is no longer relevant after employee protection against mobbing at work has been ensured by the Safety at Work Act and Regulations on Risk Assessment. Normative content of the rights, obligations and responsibilities of the parties in labour relations regarding the risk of mistreatment at work is stipulated in the relevant laws, by-laws and regulations. This legislation has been passed in order to implement EU legislation and should therefore be interpreted in accordance with the interpretations used by EU institutions and, especially, by EU Court of Justice. Croatia must also respect the obligations issuing from international agreements of the United Nations and the Council of Europe as well as the practice of their permanent bodies appointed to monitor these agreements in the member states. Interpretation must be broad in scope, so that dignity, health and safety at work are protected not only from discriminatory behaviours at work and in connection with work but also from improper and undesired behaviours that may violate the guaranteed personal rights.

Key words: dignity at work, employee health, personal rights, mistreatment, mobbing, bullying

Original scientific paper

Received: 2015-06-24

Accepted: 2015-12-14 